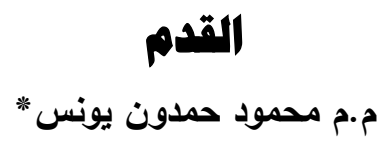

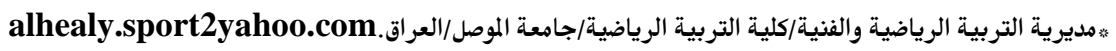

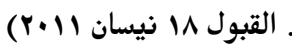

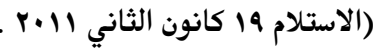

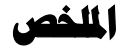

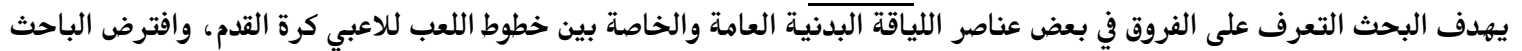

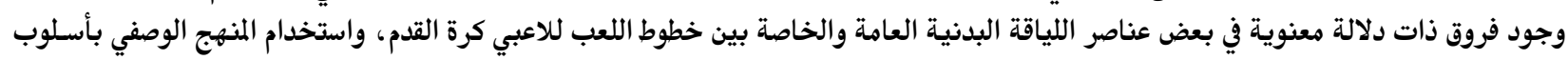

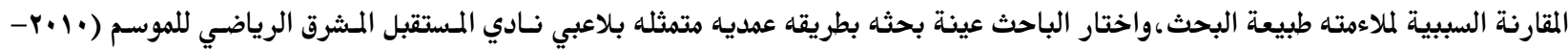

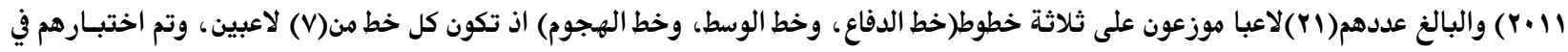

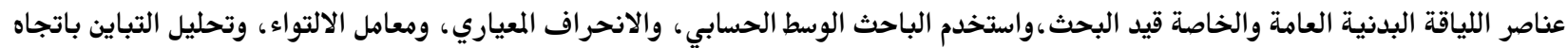

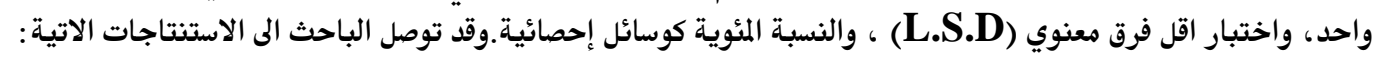

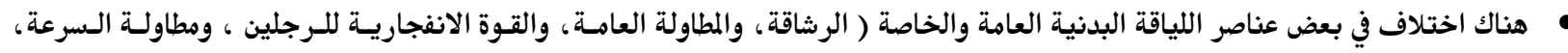

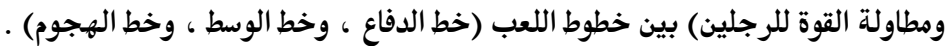

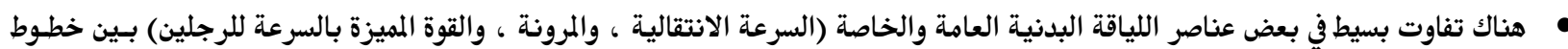

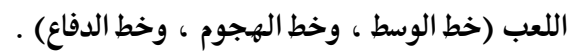
• تفوق لاعبي خط الوسط ولاعبي خط الهجوم على لاعبي خط الدفاع في عنصر الرشاقة في حين تقارب مستوى لاعبي خـط الوسط والهجـوم في عنصر الرشاقة.

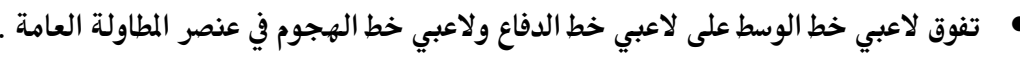

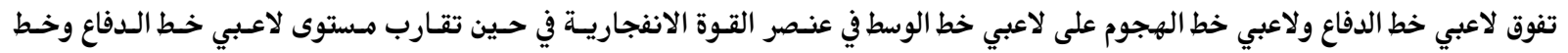

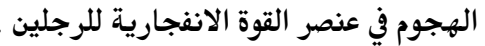

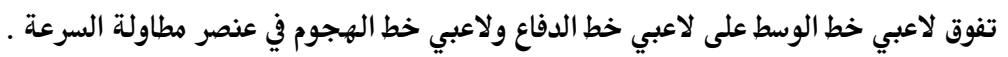

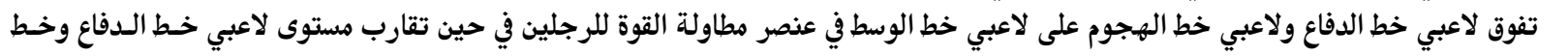

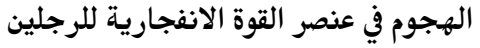

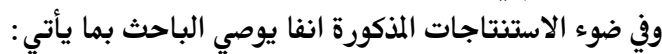

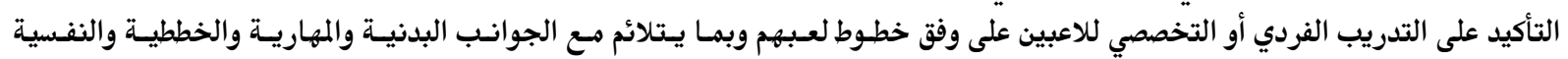
والذهنية.
\end{abstract}

\title{
A COMPARATIVE STUDY Of THE ELEMENTS OF GENERAL AND SPECIFIC PHYSICAL FITNESS AMONG FOOTBALL PLAYING LINES
}

Asist.Lecturer:Mahmood. H.Younis

\section{$\underline{\text { Abstract }}$}

The research aims at the following:

Realizing the differences in the elements of general and specific physical fitness among football playing lines. The researcher hypothesis is that significant differences are found in the elements of general and specific physical fitness among football playing lines. The descriptive method has been applied by the researcher for its convenience with the nature of the research. The research sample has been chosen intentionally represented by the players of Almustaqbal \& Almashriq football clubs for the academic year (2010-2011). The research sample has consisted of (21) players distributed on three lines (defense, middle and forward). Each line has consisted of (7) players, tested in the elements of general and specific physical fitness under discussion. The researcher has applied (arithmetic mean, standard deviation, skewness, coefficient, one-direction variation analysis and the least significant difference (LSD) test) as statistical means.

The researcher has attained the following conclusions: 
- Significant differences are found in the elements of general and specific physical fitness (agility, general endurance, legs' explosive force, legs' force endurance and speed endurance) among the (defense, middle and forward) lines.

- Non significant differences are found in the elements of general and specific physical fitness (transitional speed, flexibility, legs' force endurance and legs' speed differentiated force) among the (defense, middle and forward) lines.

- Defense and forward lines players were superior to middle line players in the elements of legs' explosive force and legs' force endurance, while the level of the defense and forward line players was convergent regarding legs' explosive force and legs' force endurance.

- Middle and forward line players were superior to defense line players in agility element, while the level of the middle and the forward line players was convergent regarding agility element.

- Middle line players were superior to defense and forward line players in speed endurance element.

- Middle line players were superior to defense and forward line players in general endurance element.

following:

In the light of the conclusions attained, the researcher has recommended the

- Individual or specific training of players pursuant to their playing lines and in convenience with the physical, skillful, planning, psychological and mental aspects should be confirmed upon.

$$
\text { 1- التعريف بالبحث: } 1 \text { - المقدمة وأهمية البحث: }
$$

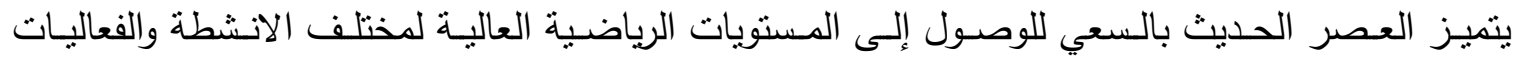

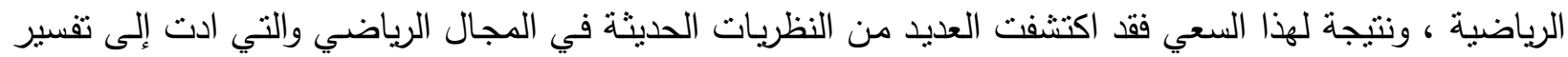

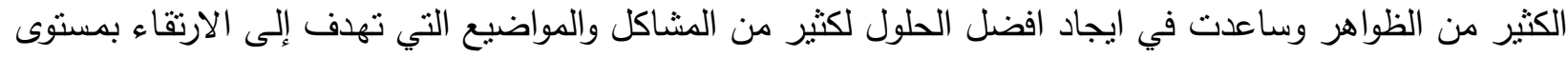

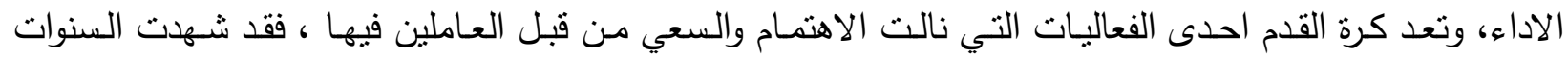

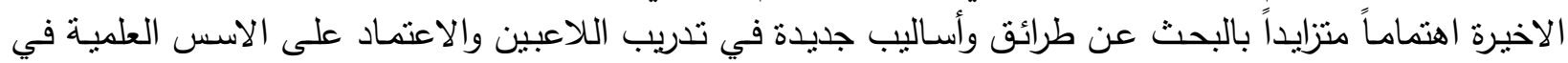

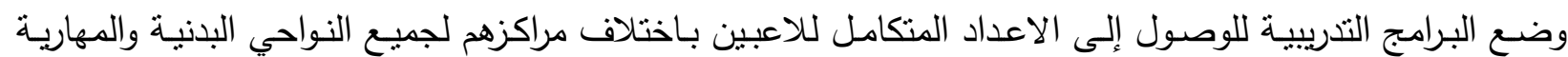

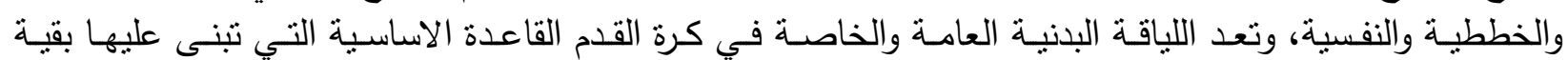

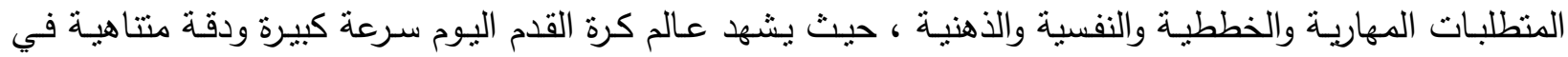
تطبيق المهارات المختلفة والمتتوعة وحسب المركز الذي يتخصص ولفي فيه اللاعب والتي تحتاج إلى علاقة وثيقة بين

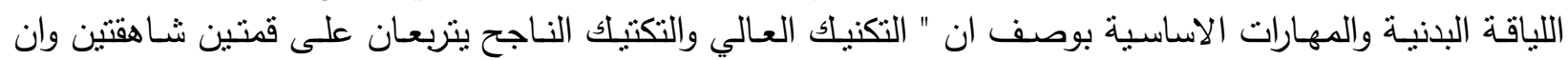

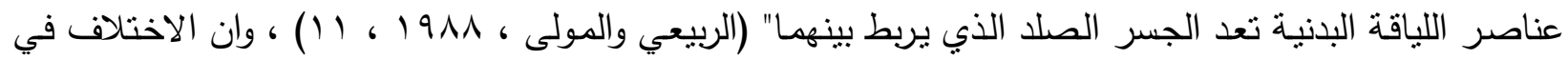

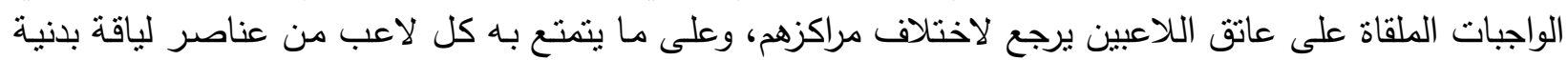

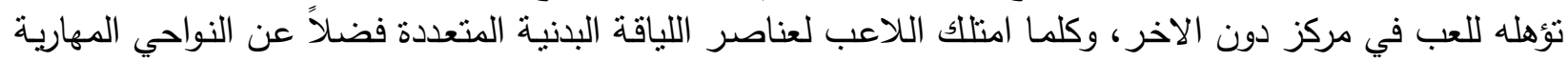

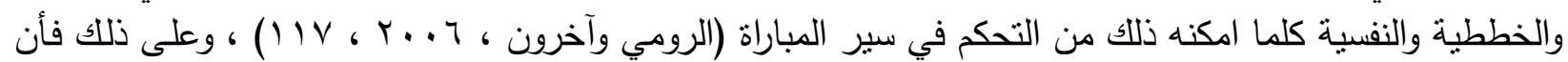

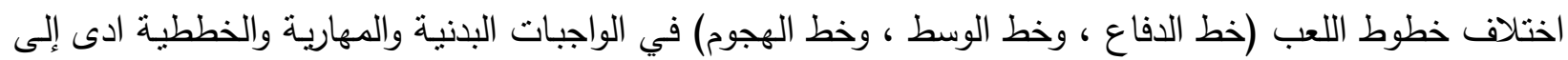

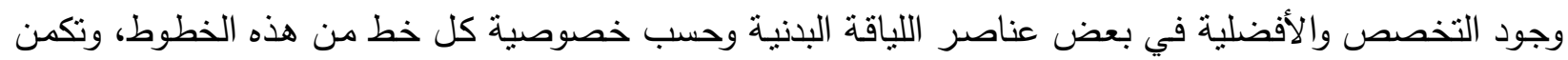

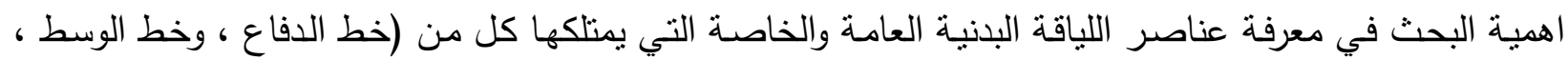

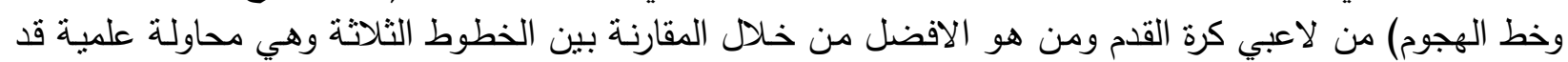

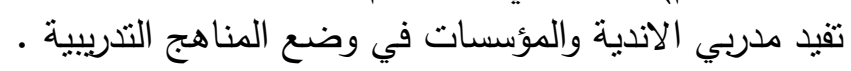
: r-1

صحيح ان كرة القدم الحديثة لخصت الأداء البدني والفني والخططي بكلمات بسيطة جداً وهي الهجوم في

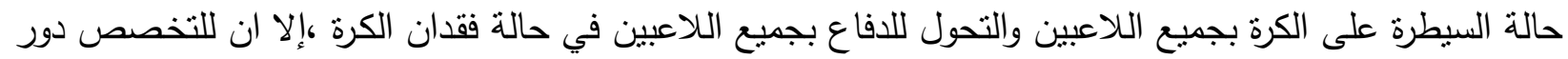

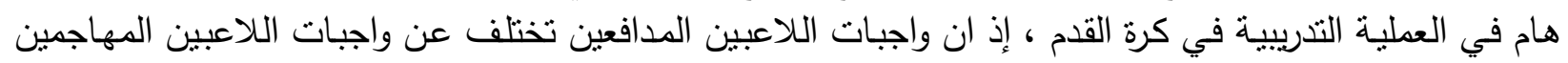


فضلاً عن اختلاف لاعبي الوسط بواجباتهم عن كل من اللاعبين المدافعين والمهاجمين ، وان الصفات البدنية العامـة

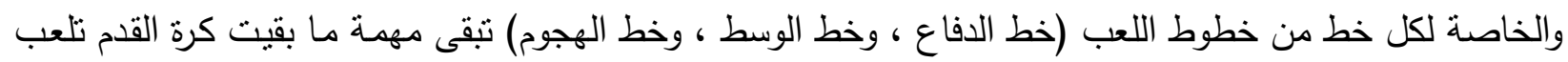

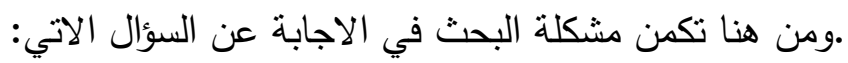

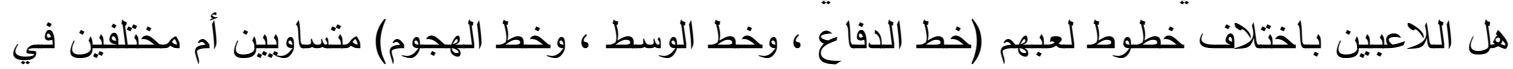

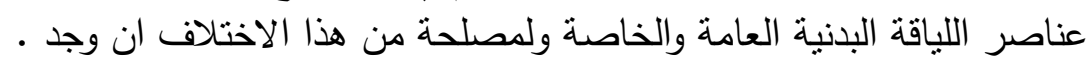
r1-r-1 الفروق في بعض عناصر اللياقة البدنية العامة والخاصة بين خطوط اللعب للاعبي كرة القدم . ( ب-1 ا - ـ - ا وجود فروق ذات دلالة معنوية في بعض عناصر اللياقة البدنية العامة والخاصة بين خطوط اللعب للاعبي كرة القدم.

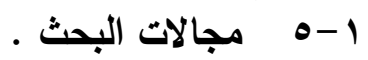

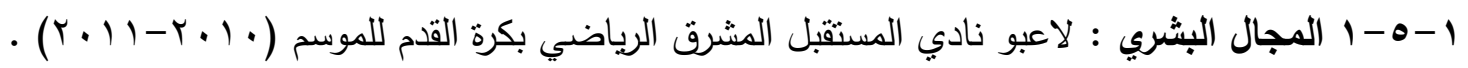

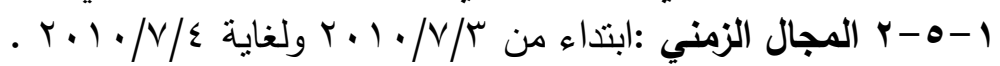

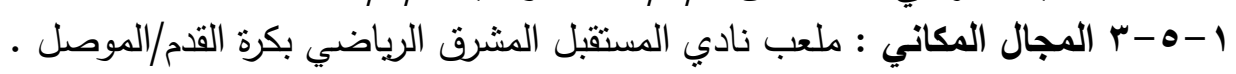

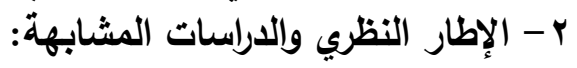
: r r r الإطار النظري r-

تعد اللياقة البدنية احد مكونات اللياقة الثاملة التي تضم اللياقة البدنية واللياقة النفسية واللياقة الاجتماعية

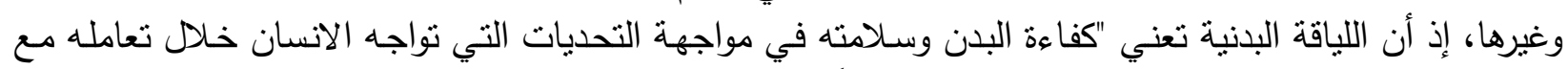

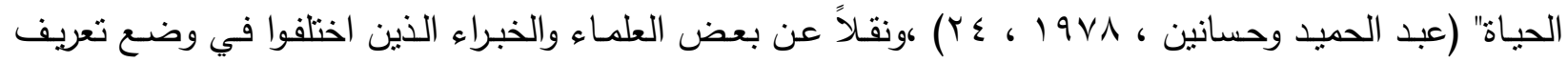

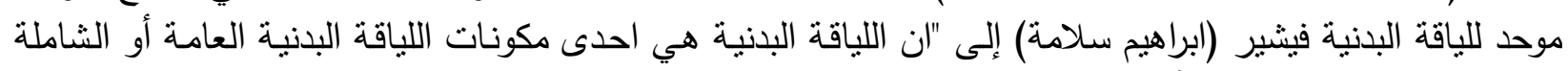

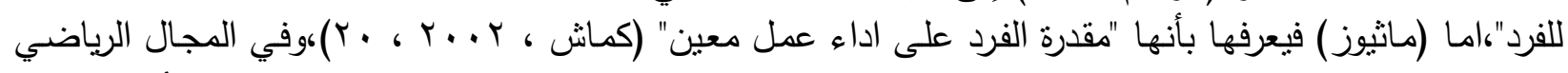

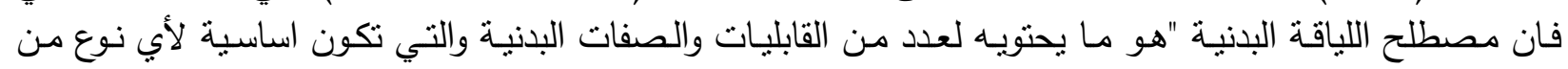

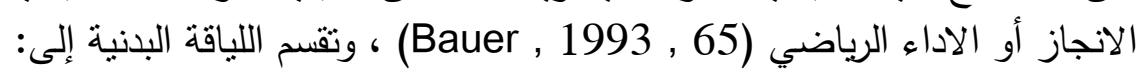

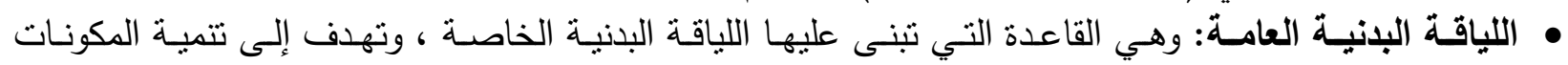

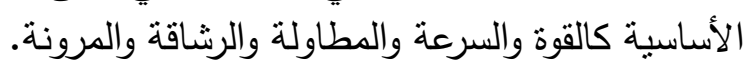

• اللياقة البذنية الخاصة: وهي كفاءة البدن في مواجهة متطلبات النشاط المعين ، وتهدف إلى تتمية مكونات معينة

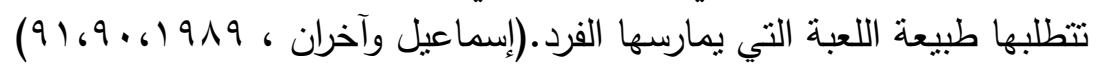

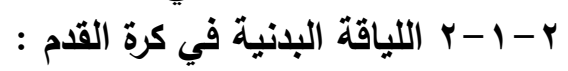

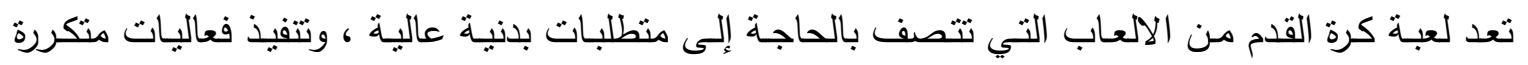

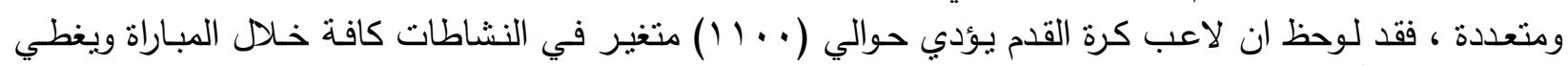

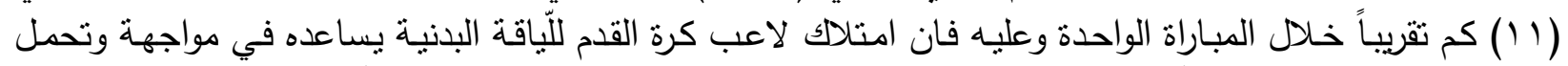

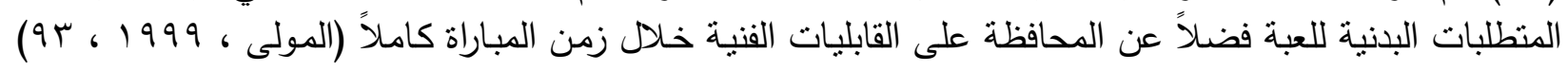

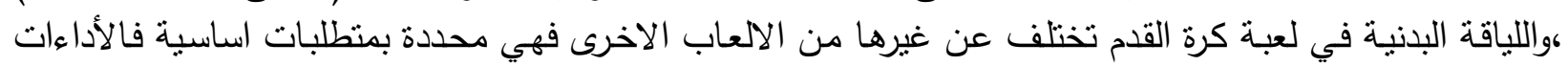

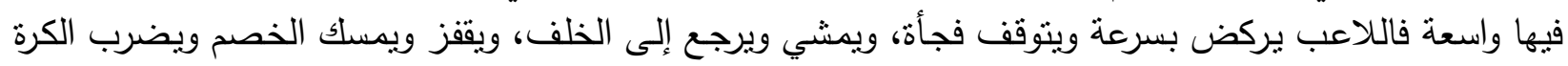

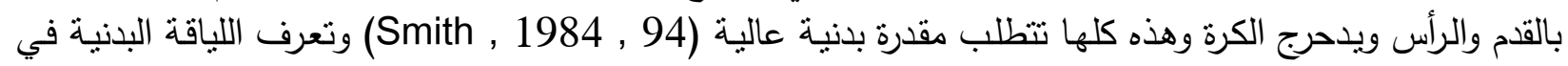

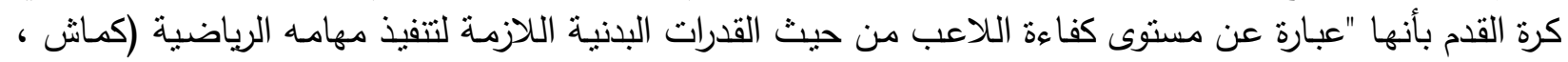

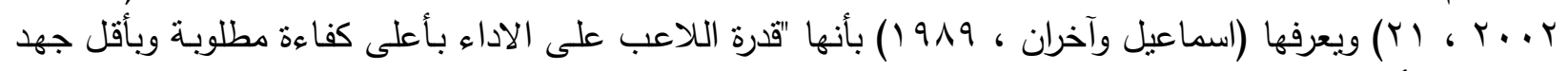

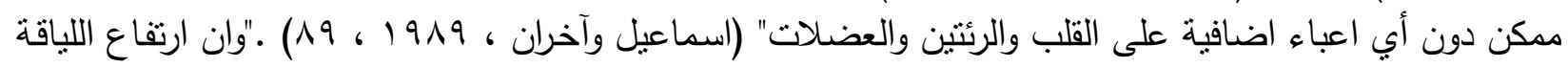

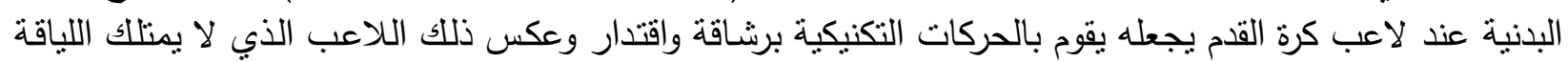

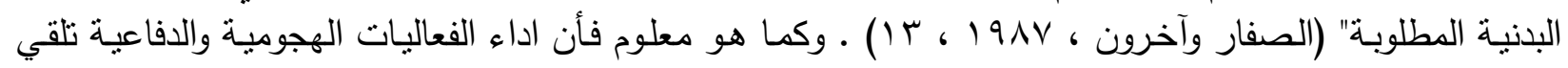

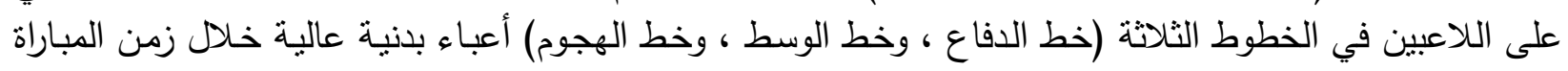


الفعلي الامر الذي يتطلب من اللاعب أداء حركياً متوازناً ومناسباً ولياقة بدنية خاصـة في كل خط بمستوى عال

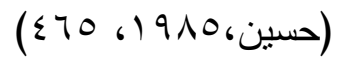
r- - r- أهمية اللياقة البدنية في كرة القدم:

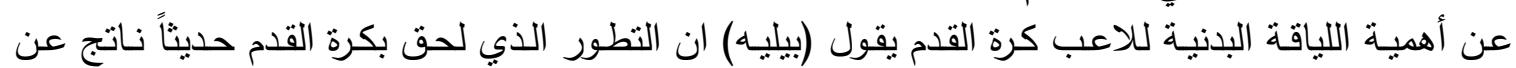

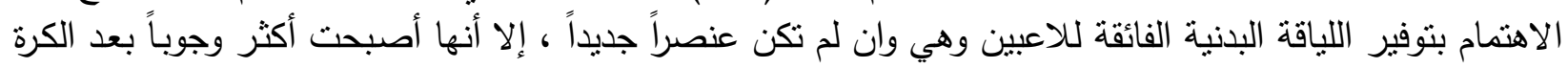

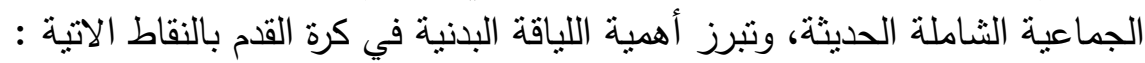

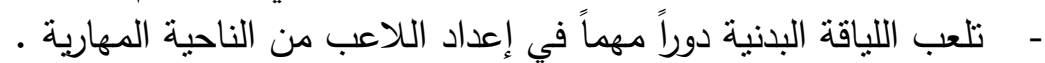

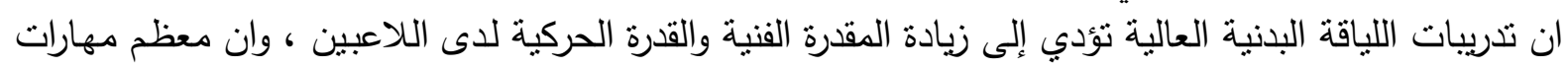
التوافق تتضمن عناصر الرشاقة والتوازن والسرعة. تلعب اللياقة البدنية دوراً اساسياً في تتفيذ خطط اللعب، فئن وني تساعد لاعبي الفريق في سرعة الرجوع لتتفيذ الخطط

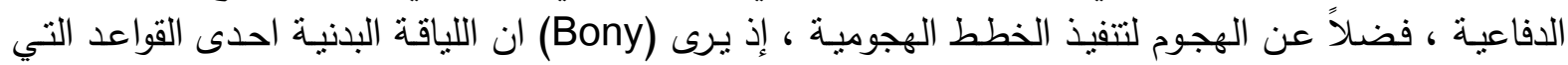

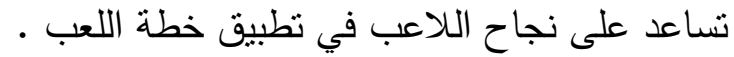

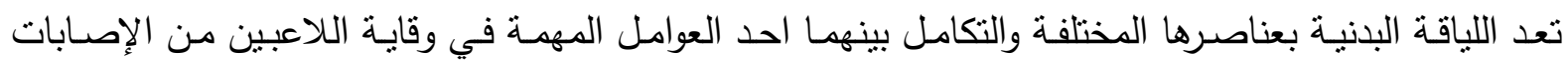

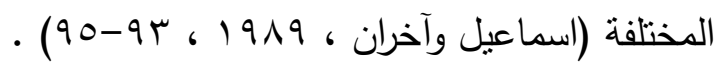
: r r r r r الداسات السابقة

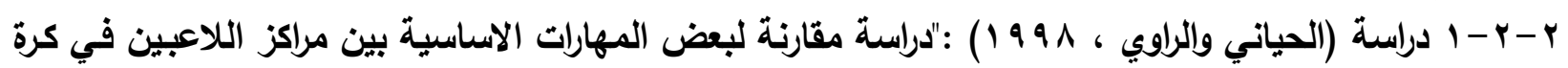
هدفت الدراسة إلى التعرف على الفروق في بعض المهارات الاساسية بين لاعبي المراكز المختلفة بكرة القدم

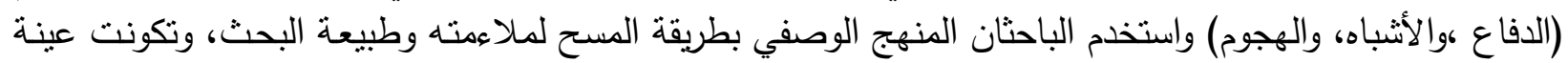

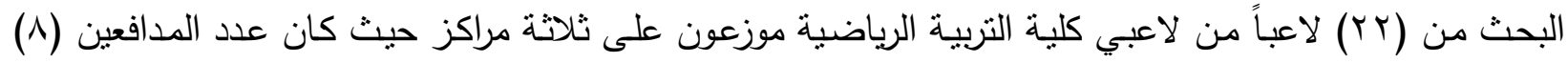

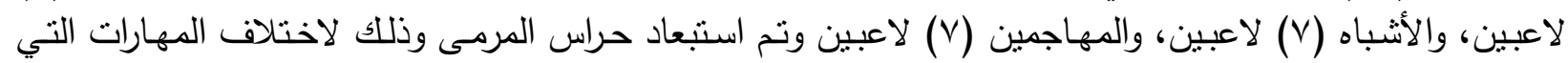

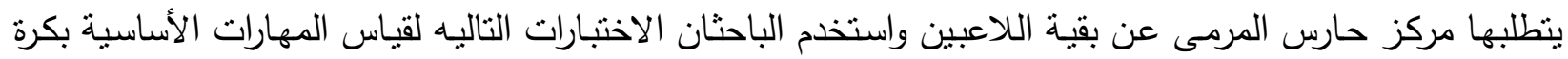
القدم (الدحرجة ، وتتطيط الكرة ، والاخماد ، وضرب الكرة لأبعد مسافة) واستخدم الباحثان الوسائل الإنئن الإنصائية الآتية

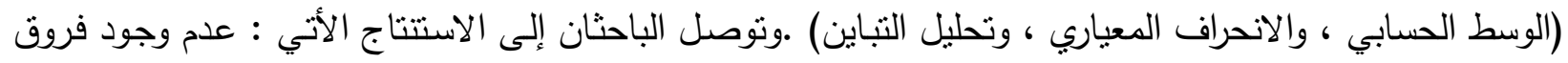

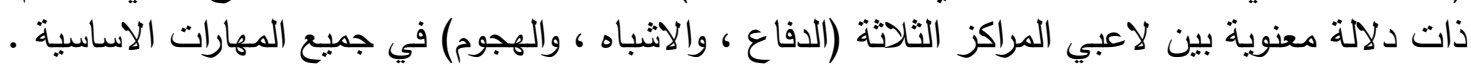

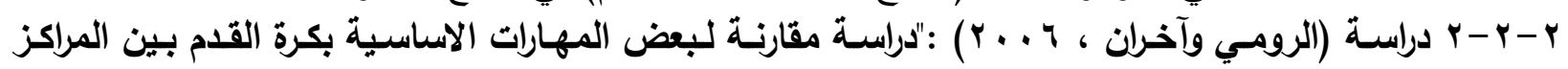

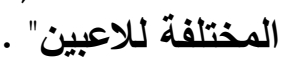
هدف البحث إلى التعرف على الفروق في بعض المهارات الاساسية بين لاعبي المراكز المختلفة بكرة القدم

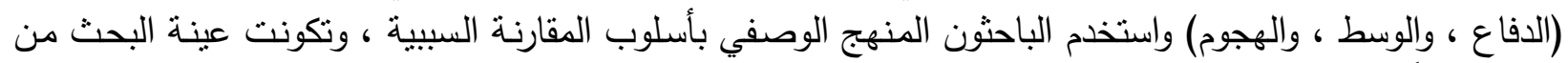

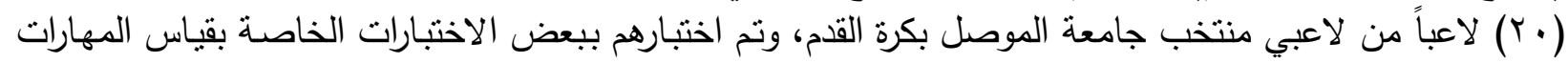
الاساسية الاتية (الاحرجة ، والمناولة القصيرة ، والاخماد ، والسيطرة على الكرة "تتطبط الكرة") ، واستخدم الباحثون

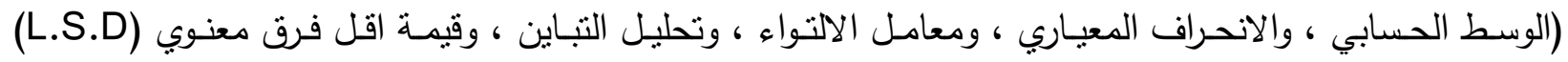
كوسائل احصائية) ،وتوصل ، والاتئل الباحثون إلى الاستتناجين الآتيين: تقارب مستوى اللاعبين على وفق مراكزهم المختلفة (الدفاع ، والوسط الإنين ، والهجوم) في المهارات الاساسية الاتية

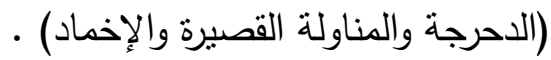

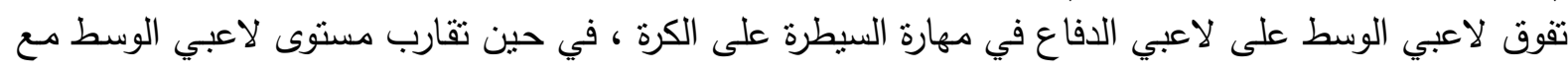

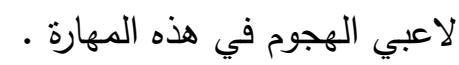

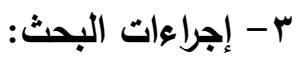

r-1 منهج البحث: استخدم الباحث المنهج الوصفي بأسلوب المقارنة السبيية لملائمته وطبيعة البحث .

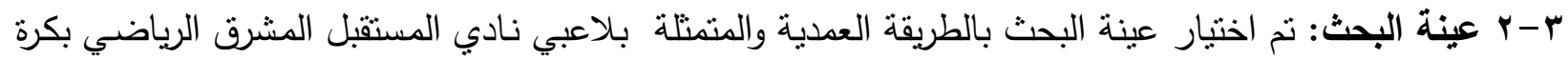

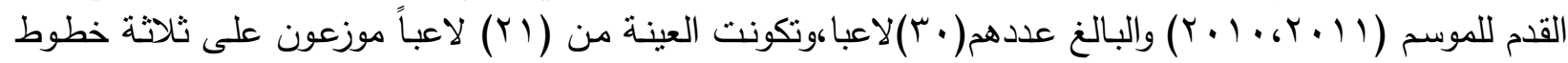

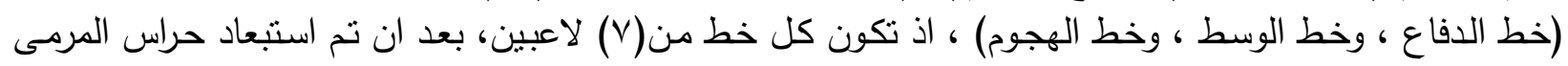


وعددهم (r) حراس، واللاعبين المصابين وعددهم(r)، فضلا عن(ع) هلاعبين لم يكملوا الاختبارات، والجدول رقم (1)

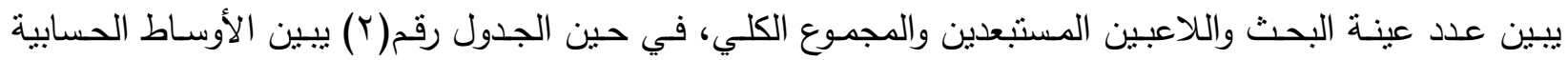
والانحرافات المعيارية ومعامل الالتواء لمتغيرات (الطول، والعدر ، والوزن) لخطوط اللعب (خط الدفاع، وخط الوسط، وخط الهجوم)

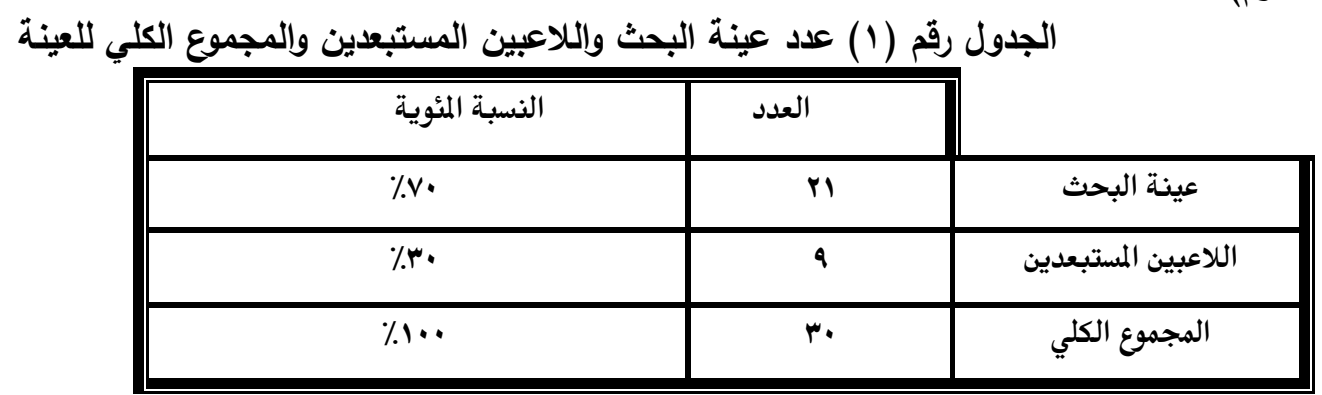

الجدول رقم (ץ)الأوساط الحسابية والانحرافات المعيارية ومعامل الالتواء لمتغيرات(الطول، والعمر، والوزن) لخطوط اللعب (خط الدفاع، وخط الوسط، وخط الهجوم)

\begin{tabular}{|c|c|c|c|c|c|c|c|c|c|c|}
\hline \multicolumn{3}{|c|}{ خط الهجوم } & \multicolumn{3}{|c|}{ خط الوسط } & \multicolumn{3}{|c|}{ خط الدفاع } & \multirow{2}{*}{ وحدة القياس } & \multirow{2}{*}{ 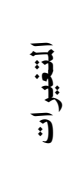 } \\
\hline معامل الالتواء & $\varepsilon^{ \pm}$ & سَ & الالتواء & $\varepsilon^{ \pm}$ & سَ س س & الالتواء & $\varepsilon^{ \pm}$ & سَ س & & \\
\hline$\cdot, V r$ & $v, I r$ & IVY, OV & •,Ar & $\Lambda, \vee \cdot$ & $|V r,| \varepsilon$ & $\cdot, 19-$ & $\theta, \Lambda V$ & $\mid v \cdot, \wedge$ & سم سم & الطول \\
\hline$\cdot, 9 \mathrm{~V}$ & $r, \wedge V$ & Yr, $\varepsilon Y$ & •,६1- & $1, r_{1}$ & rr,AQ & •, • - & r,१^ & $r \&, Y \wedge$ & سنة & العمر \\
\hline קט, • & $v, 10$ & IV,AD & $\cdot, 9$. & $\Upsilon, \vee \varepsilon$ & $97, \wedge 0$ & •,rq- & $\varepsilon, \bullet \varepsilon$ & vi & كغم & الوزن \\
\hline
\end{tabular}

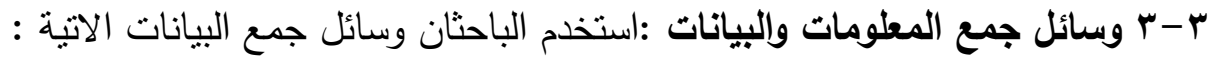

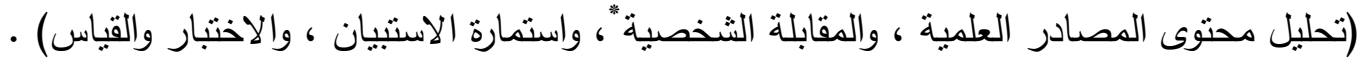

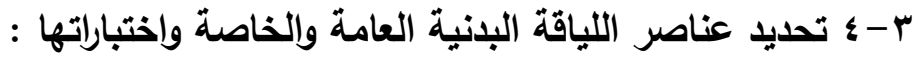

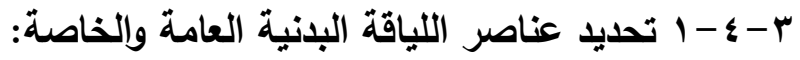

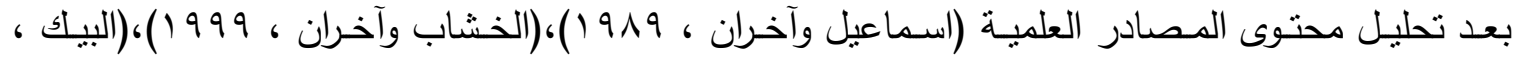

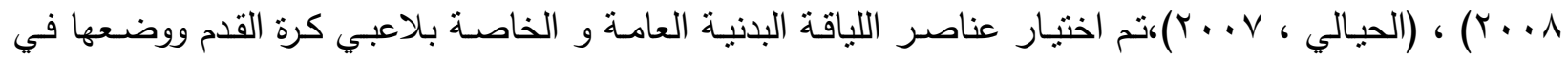

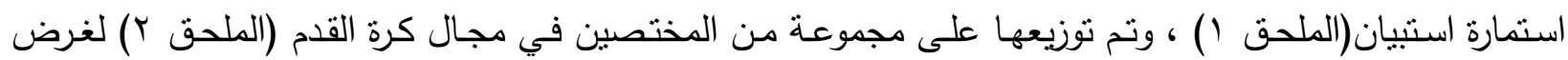

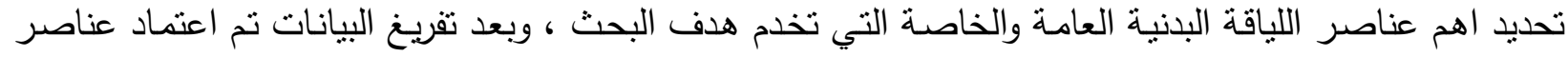

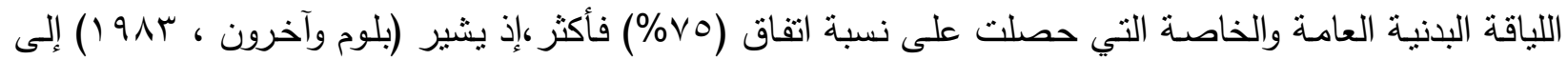

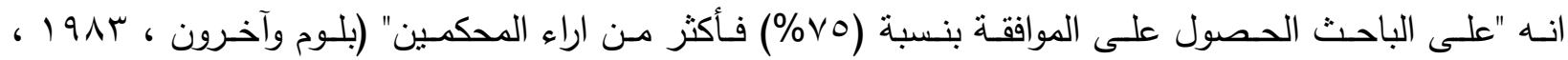
ج ب ( ).والجدول رقم (r) يبين النسب المئوية لاتفاق اراء السادة المختصين حول تحديد اهم عناصر اللياقة البدنية العامة والخاصة.

* قام الباحث بإجراء مقابلات شخصية مع السادة المختصين لغرض جمع معلومات تخدم اهداف البحث وهم:

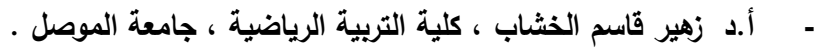

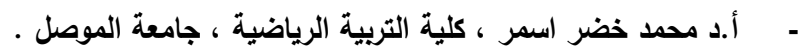

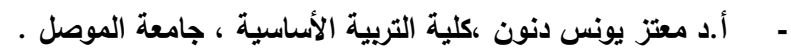

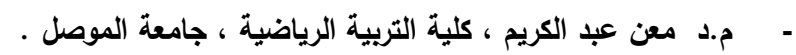


الجدول رقم (ץ) النسب المئوية لاتفاق اراء السادة المختصين حول تحديد اهم عناصر اللياقة البدنية العامة والخاصة لتلاعبي كرة القدم

\begin{tabular}{|c|c|c|c|}
\hline النسبة المئوية & عد المتفقين & عدد المختصين & عناصر اللياقة البدنية العامة والخاصة \\
\hline$\% 1 \ldots$ & 9 & 9 & السرعة الانتقالية \\
\hline$\%$ \% & $\Lambda$ & 9 & الرشاقة \\
\hline$\% 1 \ldots$ & 9 & 9 & المطاولة العامة \\
\hline$\% \mathrm{VV}, \mathrm{VV}$ & $v$ & 9 & 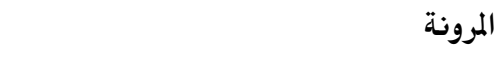 \\
\hline$\% 1 \ldots$ & 9 & 9 & القوة الانفجارية للرجلين \\
\hline$\%$ & 9 & 9 & القوة الميزة بالسرعة للرجلين \\
\hline$\% 1 \ldots$ & 9 & 9 & مطاولة السرعة \\
\hline$\% \wedge$ & $\wedge$ & 9 & مطاولة القوة للرجلين \\
\hline
\end{tabular}

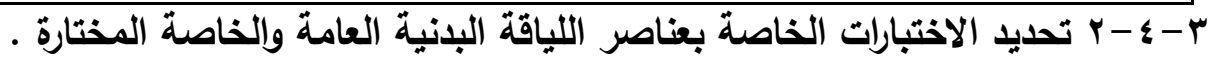

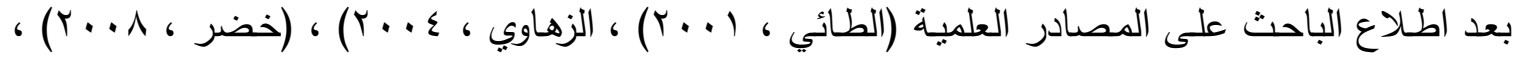

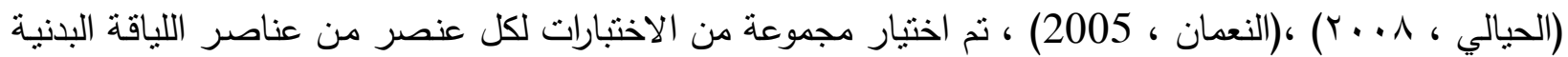

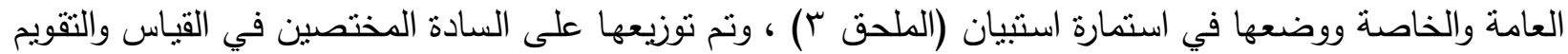
وكرة القدم (الملحق ع) وذللك لتحديد الاختبار الانسب لكل عنصر والذي يخدم هدف البحث ، وبعد تفريغ البيانات

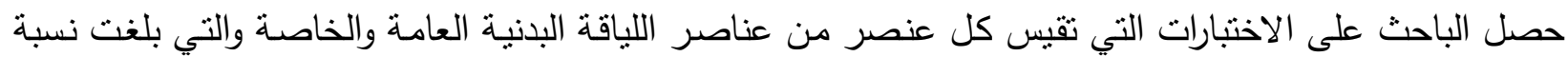

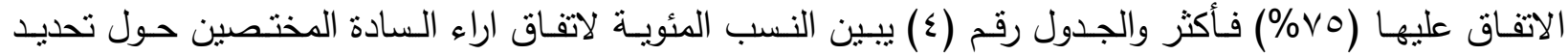

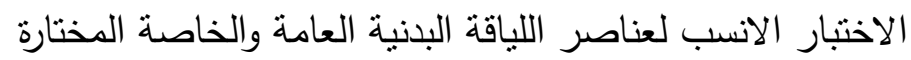

الجدول رقم (ع) النسب المئوية لاتفاق اراء السادة المختصين حول تحديد الاختبار الانسب لعناصر اللياقة البدنية العامة والخاصة المختارة

\begin{tabular}{|c|c|c|c|c|c|}
\hline النسبة المئوية & عدد المتفقين & عدد المختصين & الاختبارات & القياس & عناصر اللياقة البدنية \\
\hline$\% 91,7$ & 11 & ir & اختبار عدو · م متر من بداية متحركة & ثانية & السرعة الانتقالية الانية \\
\hline$\%$. 0 & 9 & ir & اختبار الجري المكوكي (ء××ا·)م & ثانية & 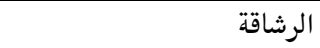 \\
\hline$\%$ & $1 \cdot$ & ir & اختبار ركض (· … متر من الوضع العالي & دقيقة & المطاولة العامة \\
\hline$\% 91,7$ & 11 & ir & ثني ومد الجذع الى الامام والاسفل من الوقوف على الصندوق & سم & 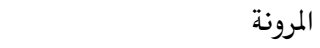 \\
\hline$\% 91,7$ & 11 & ir & اختبار القفز العمودي من الثبات & سم & القوة الانفجارية للرجلين \\
\hline$\%$ ० & 9 & ir & |ختبار ثلاث حجلات لابعد مسافة & متر & القوة المميزة بالسرعة للرجلين \\
\hline$\%$ & 1. & ir & اختبار ركض (•l\)م مرتد & ثانية & 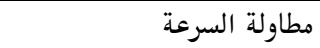 \\
\hline$\%$. 0 & 9 & ir & ثني ومد الرجلين من الركبتين حتى استنفاذ الجهد & ت تكرار & هطاولة القوة للرجلين \\
\hline
\end{tabular}

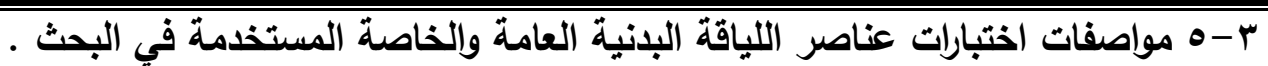

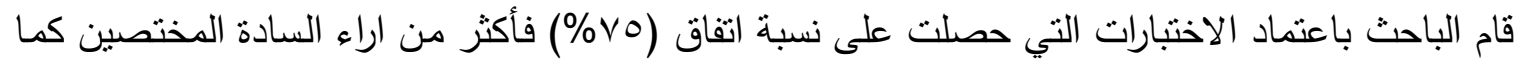

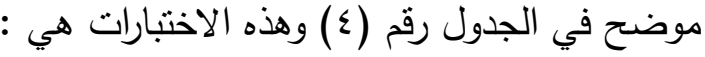

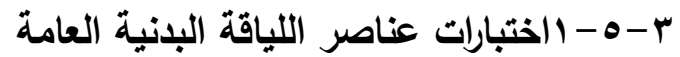

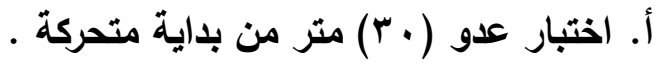

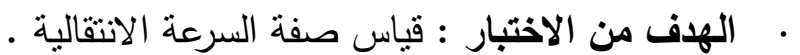

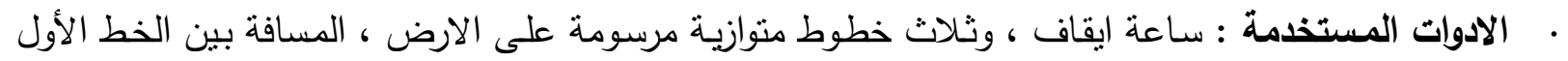

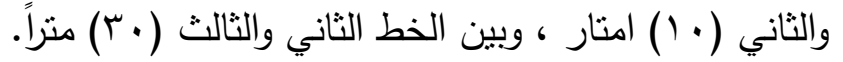


وصف الاداء : يقف المختبر خلف الخط الأول وعند سماع اشتارة البدء يقوم بالعدو إلى ان يتخطى الخط

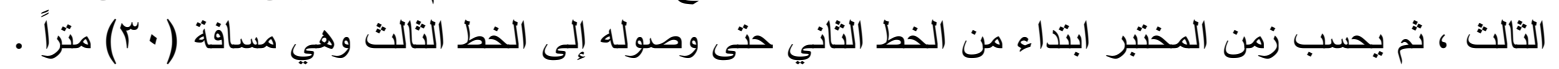

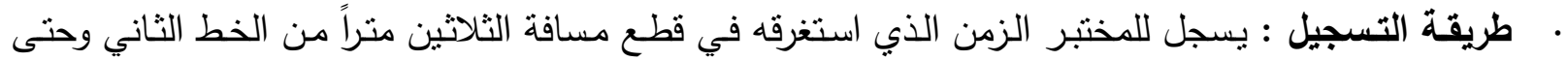

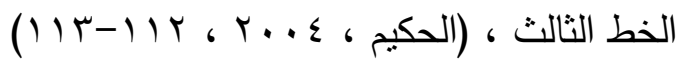

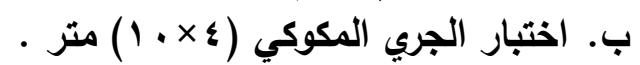

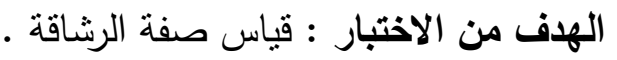

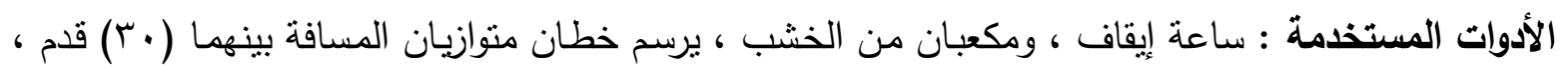

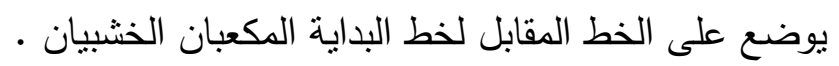
وصف الاختبار :

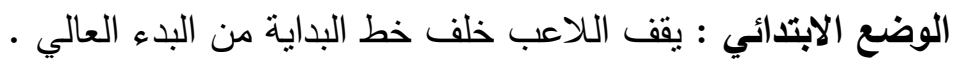
• طريقة الأداء : العدو بأقصى سرعة نحو احد المكعبين ليأخذ احدهما ويعود لوضعه على خط البداية ، ثم يكرر

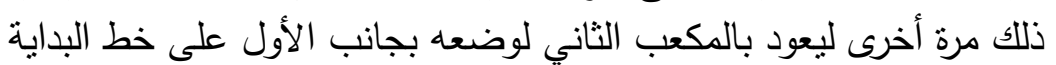

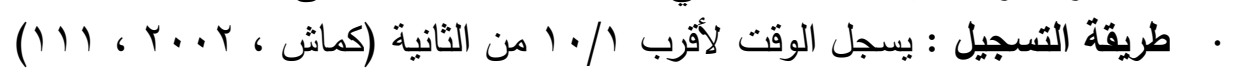

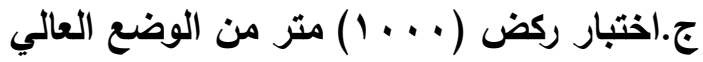
• الهرف من الاختبار :قياس كفاءة الجهازين الدوري والتبفي الوفي (المطاولة العامة).

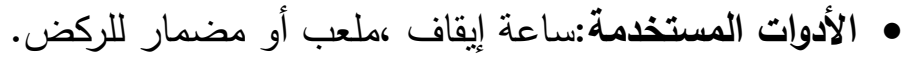

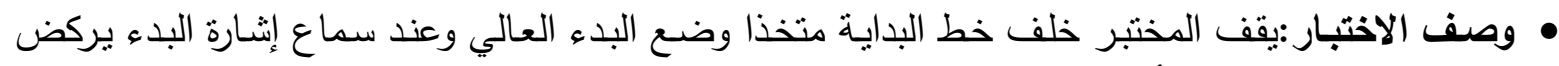
ليقطع المسافة المحددة بأقصى سرعة واقل زمن ممكن حتى يجتاز خط النهاية. • التسجيل:يسجل الزمن الذي سجله المختبر في قطع المسافة المحددة بالدقيقة ولأقرب (1 ل . . •) من الثانية.

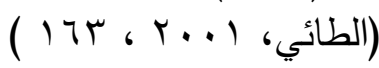

د.اختبار ثني ومد الجذع الى الامام والاسفل من الوقوف على الصندوق.

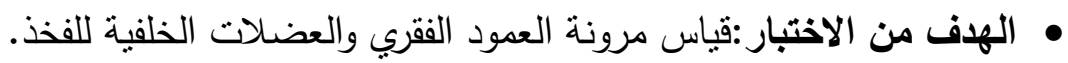

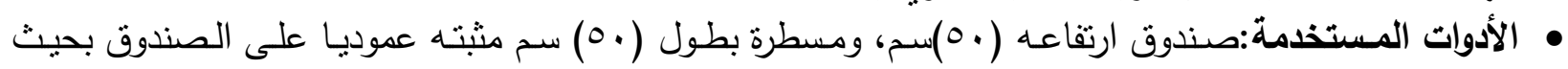

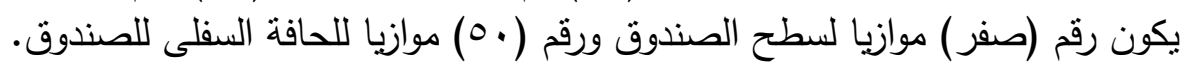

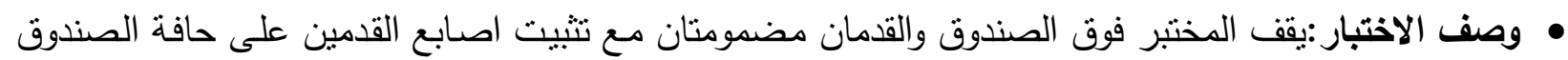

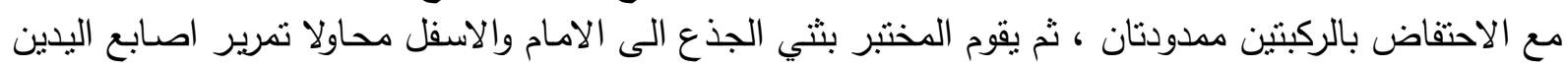

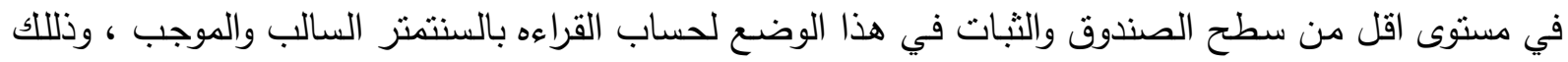

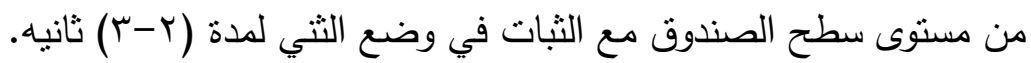

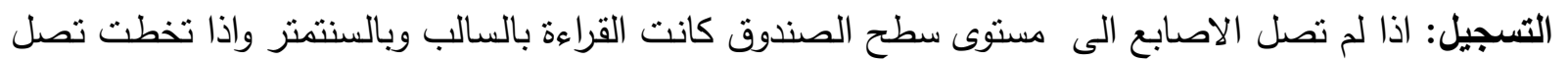

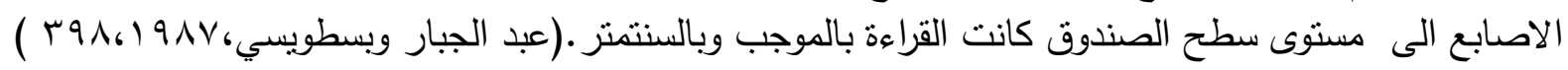

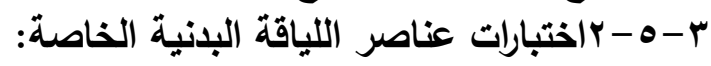

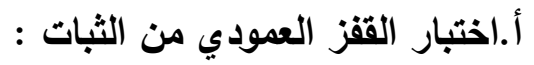

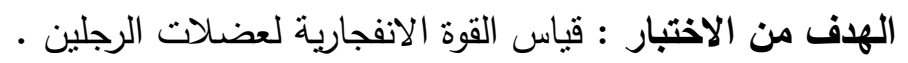

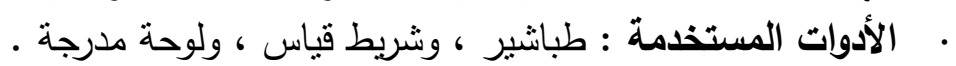

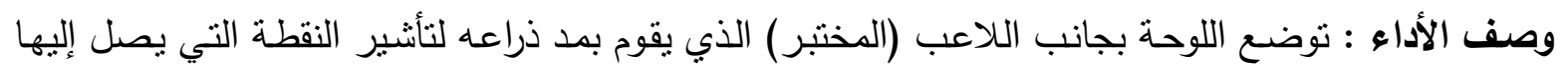

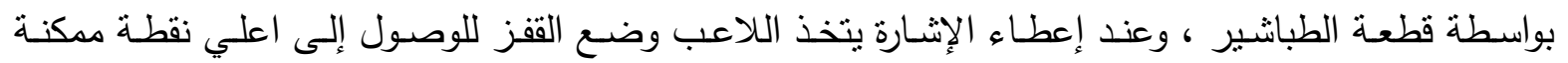

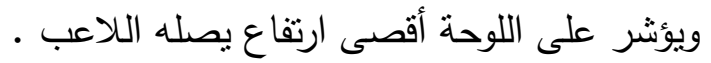
طريقة التسجيل : تقاس المسافة بين الإشـارة الأولى والثانية ويسجل الرقم وتعطى للاعب محاولتان وتحتسب

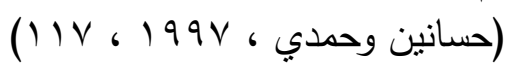

الأفضل.

ب.اختبار ثلاث حجلات لأبعد مسافة ولكل رجل على حدا :

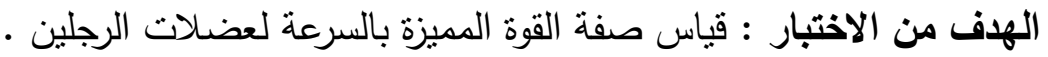

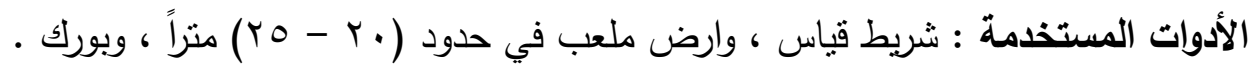




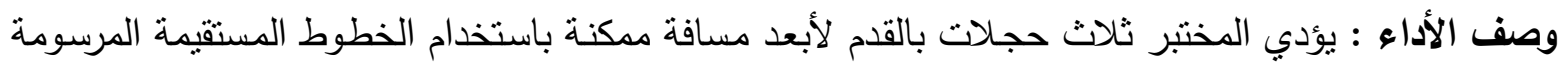

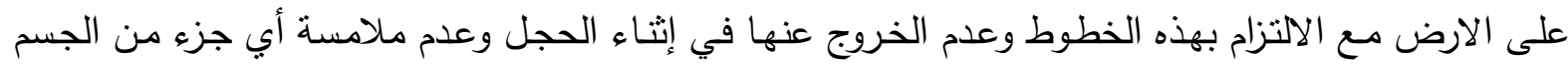

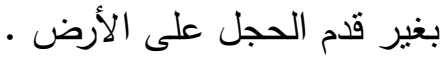

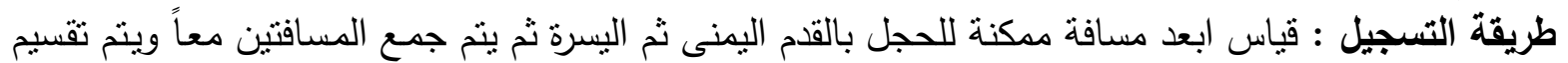

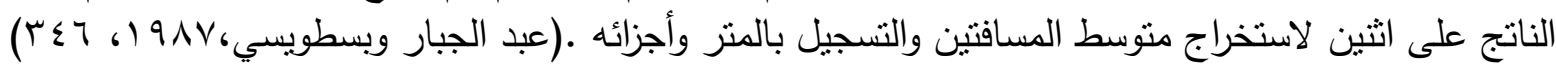

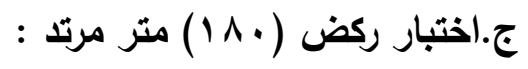

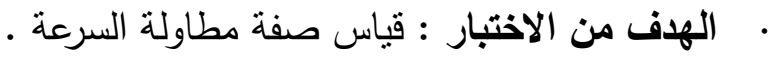

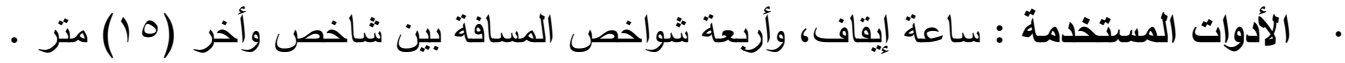

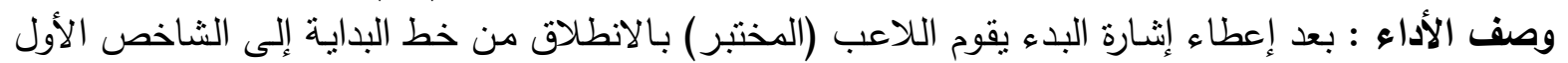

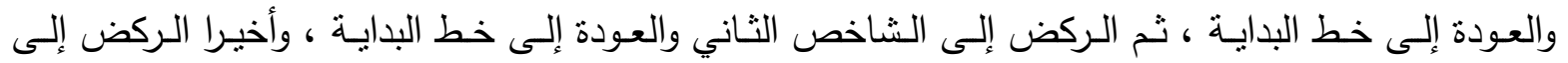

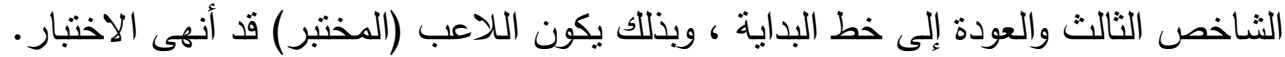

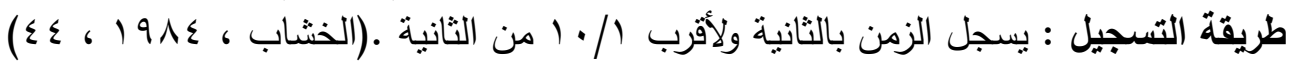

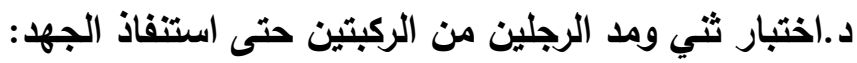
الهذف من الاختبار :قياس مطاولة القوة للرجلين.

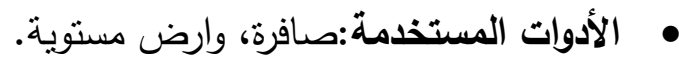

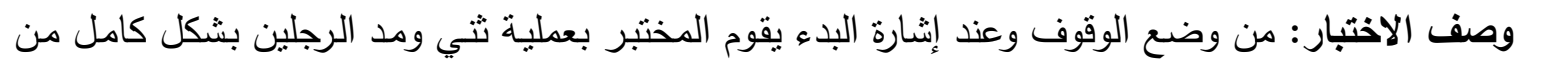

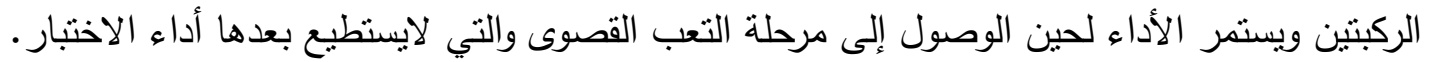
ا التسجيل: يتم تسجيل عدد المرات ثني ومد الرجلين كاملا من مفصل الركبنتين.

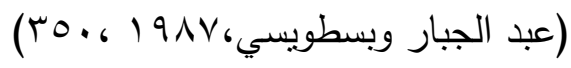
ب- r الأجزة والأدوات المستخدمة في البحث :

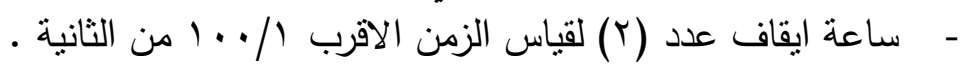

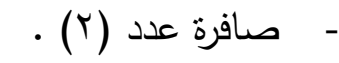

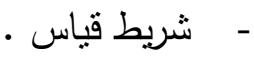

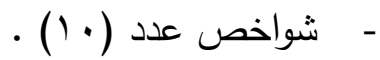

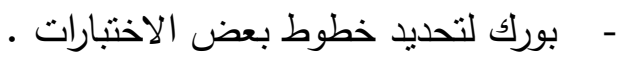
· -

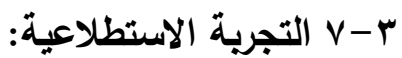

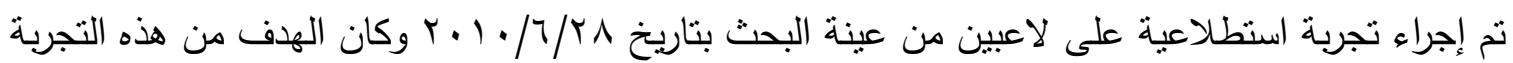

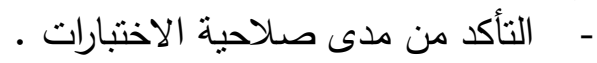

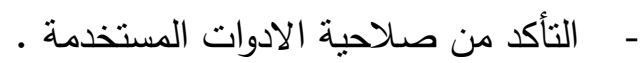
- تعرف فريق العمل المساعد" على كيفية العمل وطريقة التسجيل .

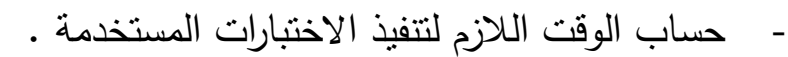

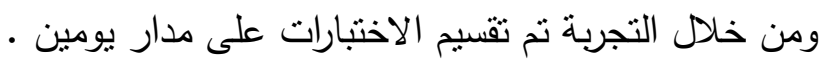

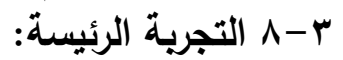

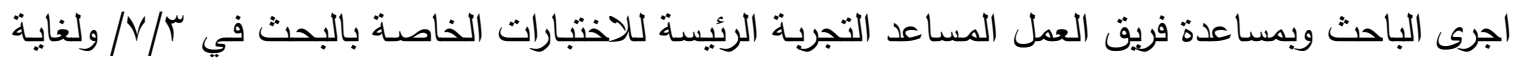

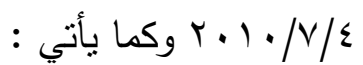

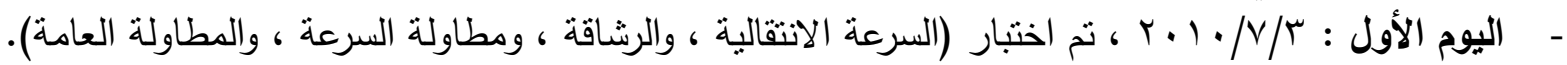




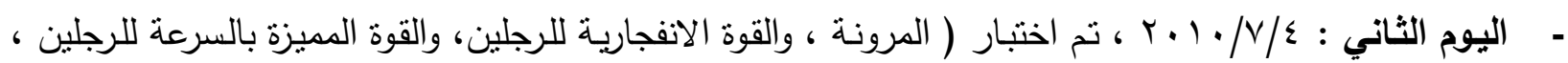

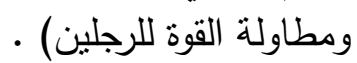

ب-9 الوسائل الإحصائية :تم استخدام الوسائل الإحصائية من خلال لإلم الاعتماد على الحقيبة الإحصائية (spss)

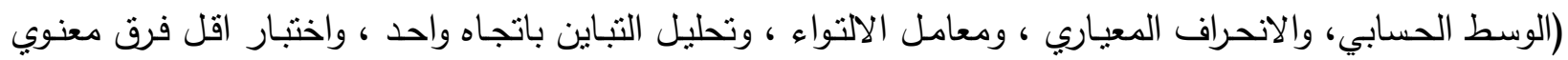
• (L.S.D) ع - عرض وتحليل ومناقشة النتائج:بعد الحصول على البيانات الخاصـة بالبحث تمث معالجتها احصائياً وذلك من

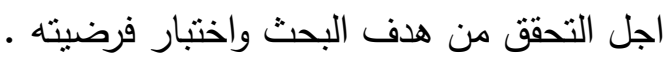

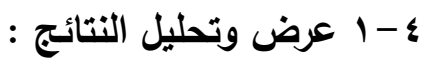

الجدول رقم (•) الأوساط الحسابية والانحرافات المعيارية ومعامل الالتواء وقيمة (ف المحسوية) ونسبة الخطأ والدلالة

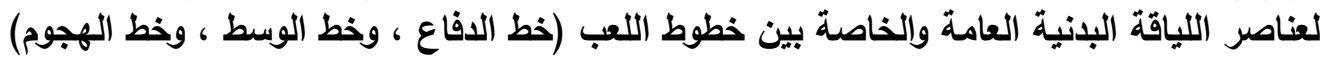

\begin{tabular}{|c|c|c|c|c|c|c|c|c|c|c|c|c|c|}
\hline \multirow[t]{2}{*}{ الدلالة } & \multirow{2}{*}{ الخطأ " الخبة } & \multirow{2}{*}{ المحسو } & \multicolumn{3}{|c|}{ خط الهجوم } & \multicolumn{3}{|c|}{ خط الوسط } & \multicolumn{3}{|c|}{ خط الدفاع } & \multirow{2}{*}{ وحدة القياس } & \multirow{2}{*}{ البدنية العامة اللياقة } \\
\hline & & & الالتواء & $\varepsilon^{ \pm}$ & سَ & الالتواء & $\varepsilon^{ \pm}$ & سَ & الالتواء & $\varepsilon^{ \pm}$ & سَ & & \\
\hline غير & • & 1,11 & $\cdot, \wedge \cdot$ & $\cdot, 11$ & r,q६ & $\cdot, r v-$ & $\cdot, 19$ & $r, \Lambda \Lambda$ & $\cdot, 19$ & $\cdot, Y \varepsilon$ & $r, q r$ & ثانية & الانتقاليـة \\
\hline معنوي & $\cdot, \cdots \wedge$ & $q, \mu$ & $\cdot, \mathrm{Mq}_{-}$ & $\cdot, 1 \varepsilon$ & $9, \cdot 1$ & $\cdot, \wedge \varepsilon$ & $\cdot, r \mu$ & 9,10 & $\cdot, 90$ & r & $9, \varepsilon V$ & ثانيـة & الرشاقة \\
\hline معنوي & $\cdot, \cdot r$ & $\varepsilon, r V$ & $\cdot, 01-$ & $\cdot, Y \varepsilon$ & $\varepsilon, \cdot r$ & $\cdot 94$ & $\cdot, \mu$ & $r, \Delta 0$ & $\cdot, \wedge 0-$ & • & $r, 91$ & دقيقة & المطاولة لعامة \\
\hline غعنوير & $\cdot, \mathrm{V \Lambda}$ & $\cdot, r \varepsilon$ & $\cdot, r_{1}$ & $r, q$ & $1 \varepsilon, \wedge 0$ & • & r,vo & $10, v 1$ & $\cdot, 9 \cdot-$ & $r, \& q$ & $10, v 1$ & سم سم & المرونة \\
\hline معنوي & $\cdot, \cdot \varepsilon$ & $r, v r$ & $\cdot, 17$ & $\varepsilon, \cdot V$ & $\mu \wedge, v\rangle$ & $\cdot, Y \varepsilon-$ & $r, r r$ & Mr,IE & " & $\bullet, \wedge \bullet$ & rq & سم & القوة الانفجارية \\
\hline غعنوير & $\cdot, \wedge 9$ & $\cdot, 1$. & •, & $\cdot, r q$ & $\Upsilon, \diamond 0$ & $\cdot, Y q-$ & $\cdot, \wedge 1$ & 9,00 & $\cdot, 9 \varepsilon-$ & $\cdot, Y_{0}$ & 7,77 & متر & للقالسرعة المميزة \\
\hline معنوي & $\cdot, \cdot r$ & $\varepsilon, \wedge \vee$ & • & • & $r r, v i$ & $\cdot, r \circ-$ & $\cdot, r V$ & MI,qV & $\cdot, 0 \varepsilon-$ & $\cdot$, TV & rr,A. & ثانيـة & مطاولة السرعة \\
\hline معنوي & $\cdot, \cdot r$ & $\varepsilon, 07$ & $\cdot, 99$ & 1, Ir & $\varepsilon r, v\}$ & $\cdot, 1 \cdot-$ & $r, \varepsilon \theta$ & $r \varepsilon, v)$ & $\cdot, 00$ & $\Lambda, 9 V$ & $\varepsilon 4,1 \varepsilon$ & تكرار & ملاولة القوة \\
\hline
\end{tabular}

من خلال الجدول رقم (0) يتنين لنا ما يأتي : - هنـاك فروق معنويـة في عناصـر اللياقـة البدنيـة العامـة والخاصـة (الرشـاقة ، والمطاولـة العامـة، والقوة الانفجاريـة

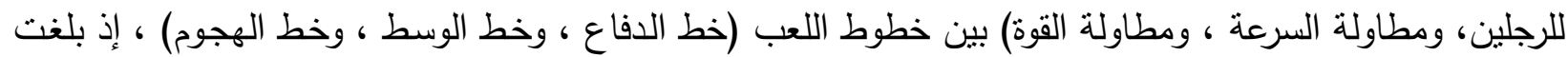

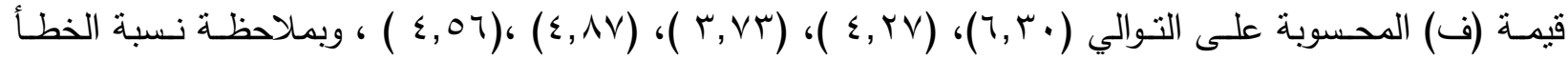

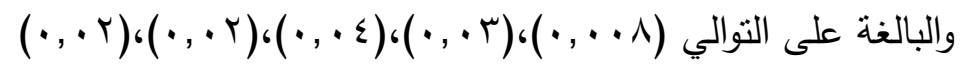

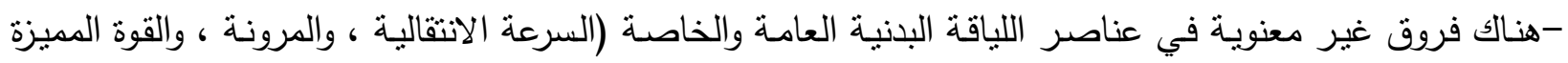

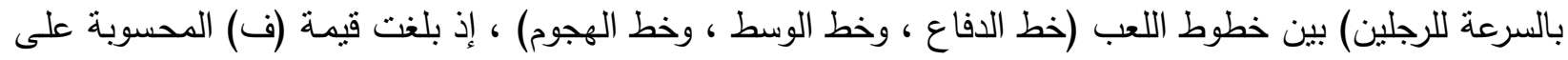
التوالي (1)

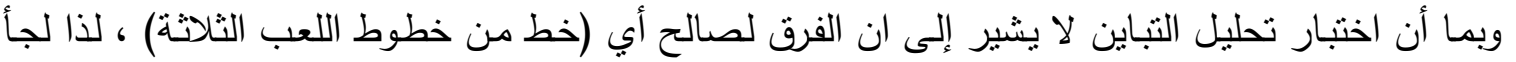

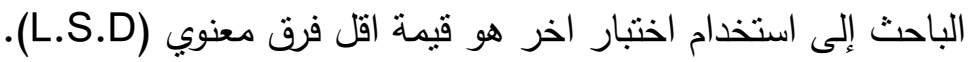

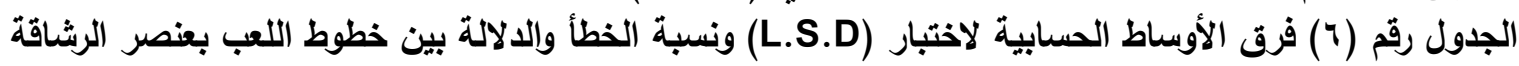


دراسة مقارنة لبعض عناصر الياقة البدنية. ....

\begin{tabular}{|c|c|c|c|}
\hline الدلالة & نسبة الخطأ & فرق الأوساط الحسابية & خطوط اللعب \\
\hline معنوي & $\cdot, \cdot r$ & •, Hr & خط الدفاع - خط الوسط \\
\hline معنوي & $\cdot, \cdot r$ & $\cdot, 87$ & خط الدفاع - خط الهجوم \\
\hline غير معنوي & $\cdot, r \cdot$ & $\cdot, 1 \varepsilon$ & خط الوسط - خط الهجوم \\
\hline
\end{tabular}

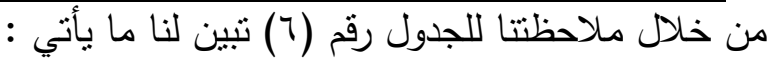

- هناك فرق معنوي في عنصر الرشاقة بين خطي الدفاع والوسط ولمصلحة خط الوسط ، إذ بلغت نسبة الخطأ لفرق الأوساط (r • , •) .

- هناك فرق معنوي في عنصر الرشاقة بين خطي الدفاع والهجوم ولمصلحة خط الهجوم ، إذ بلغت نسبة الخطأ

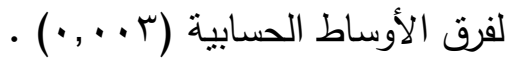
- هنـاك فرق غير معنوي في عنصر الرشّاقة بين خطي الوسط والهجوم إذ بلغت نسبة الخطـأ لفرق الأوسـاط

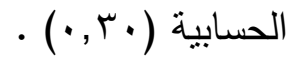

الجدول رقم (V) فرق الأوساط الحسابية لاختبار (L.S.D) ونسبة الخطأ والدلالة بين خطوط اللعب بعنصر المطاولة العامة

\begin{tabular}{|c|c|c|c|}
\hline الدلالة & نسبة الخطأ & فرق الأوساط الحسابية & خطوط اللعب \\
\hline معنوي & $\cdot, \cdot \varepsilon$ & • ro & خط الدفاع - خط الوسط \\
\hline غير معنوي & $\cdot, 01$ & $\cdot, 11$ & خط الدفاع - خط الهجوم \\
\hline معنوي & $\cdot, \cdot 1$ & $\cdot, \Sigma 7$ & خط الوسط - خط الهجوم \\
\hline
\end{tabular}

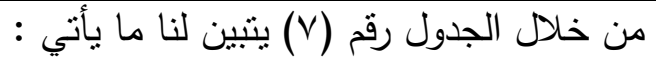

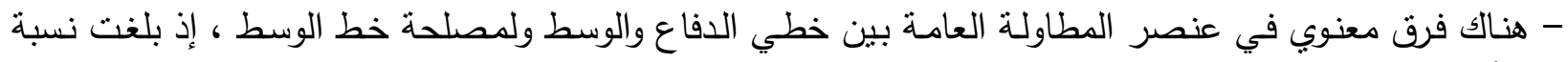
الخطأ لفرق الأوساط الحسابية (ع في ف . • ).

- هنالك فرق معنوي في عنصر المطاولة العامة بين خطي الوسط والهجوم ولمحصلة خط الوسط ، إذ بلغت نسبة

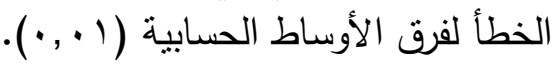

- هناك فرق غير معنوي في عنصر المطاولة العامة بين خطي الدفاع والهجوم ، إذ بلغت نسبة الخطأ لفرق

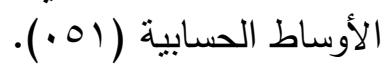
الجدول رقم (^) فرق الأوساط الحسابية لاختبار(L.S.D) ونسبة الخطأ والدلالة بين خطوط اللعب بعنصر القوة الانفجارية

\begin{tabular}{|c|c|c|c|}
\hline الدلالة & نسبة الخطأ & فرق الاوساط الحسابية & خطوط اللعب \\
\hline معنوي & $\cdot, \cdot r$ & $0, \wedge 0$ & خط الدفاع - خط الوسط \\
\hline غير معنوي & $\cdot, 9$. & $\cdot, \mathrm{M}$ & خط الدفاع - خط الهجوم \\
\hline معنوي & $\cdot, \cdot r$ & $0,0 \mathrm{~V}$ & خط الوسط - خط الهجوم \\
\hline
\end{tabular}

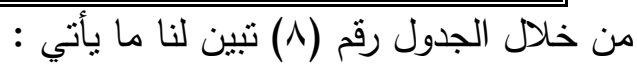

- هناك فرق معنوي في القوة الانفجاريـة للرجلين بين خطي الدفاع والوسط ولمصلحة خط الدفاع ، إذ بلغت

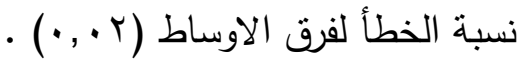

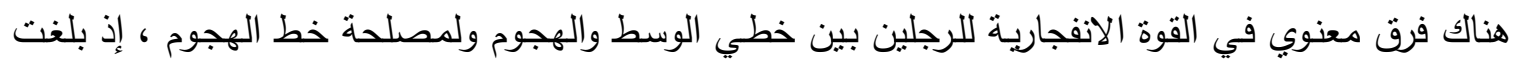

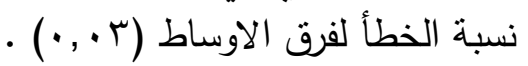
هناك فرق غير معنوي في القوة الانفجارية للرجلين بين خطي الدفاع والهجوم ، إذ بلغت نسبة الخطأ لفرق

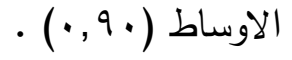


الجدول رقم (9) فرق الأوساط الحسابية لاختبار (L.S.D) ونسبة الخطأ والدالالة بين خطوط اللعب بعنصر مطاولة السرعة

\begin{tabular}{|c|c|c|c|}
\hline الدلالة & نسبة الخطأ & فرق الاوساط الحسابية & خطوط اللعب \\
\hline معنوي & $\cdot, \cdot 1$ & $\cdot, \lambda r$ & خط الدفاع - خط الوسط \\
\hline غير معنوي & $\cdot, \sqrt{ } 4$ & $\cdot, \cdot 9$ & خط الدفاع - خط الهجوم \\
\hline معنوي & $\cdot, \cdot r$ & $\cdot, \mathrm{Vr}$ & خط الوسط - خط الهجوم \\
\hline
\end{tabular}

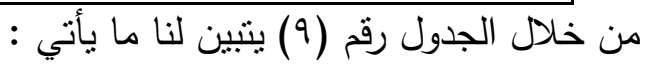

- - هناك فرق معنوي في عنصر مطاولة السرعة بين خطي الدفاع والوسط ولمصلحة خط الوسط ، إذ بلغت

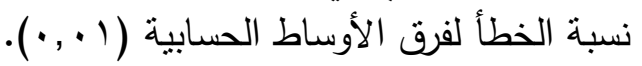
هناك فرق معنوي في عنصر مطاولة السرعة بين خطي الوسط والهجوم ولمصلحة خط الوسط ، إذ بلغت

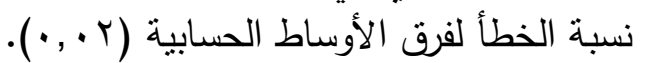
هناك فرق غير معنوي في عنصر مطاولة السرعة بين خطي الدفاع والهجوم ، إذ بلغت نسبة الخطأ لفرق

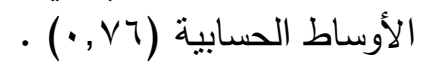
الجدول رقم ( • ()فرق الأوساط الحسابية لاختبار (L.S.D) ونسبة الخطأ والدلالة بين خطوط اللعب بعنصر مطاولة القوة

\begin{tabular}{|c|c|c|c|}
\hline الدلالة & ن نسبة الخطأ & فرق الأوساط الحسابية & خطوط اللعب \\
\hline معنوي & $\cdot, \cdot 1$ & $11, \varepsilon Y$ & خط الدفاع - خط الوسط \\
\hline غير معنوي & $\cdot, \infty 0$ & $r,\{Y$ & خط الدفاع - خط الهجوم \\
\hline معنوي & $\cdot, \cdot r$ & 9 & خط الوسط - خط الهجوم \\
\hline
\end{tabular}

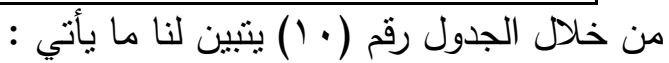

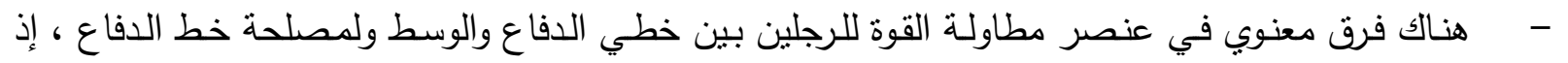

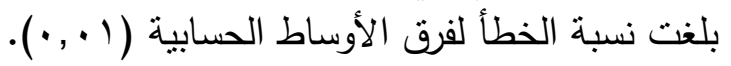

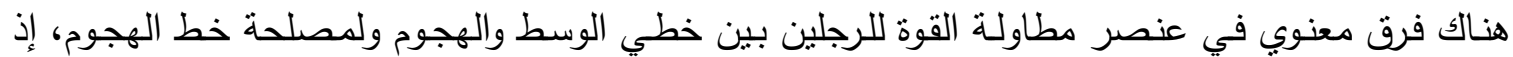

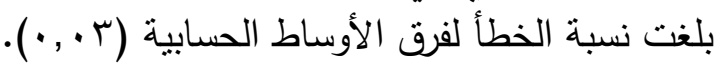
هنالك فرق غير معنوي في عنصر مطاولـة القوة للرجلين بين خطي الدفاع والهجوم ، إذ بلغت نسبة الخطأ لفرق الأوساط الحسابية (00, • •) .

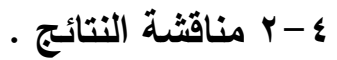

يتبين من الجدول رقم (0) وجود فروق غير معنوية بين خطوط اللعب (خط الدفاع ، وخط الوسط ، وخط

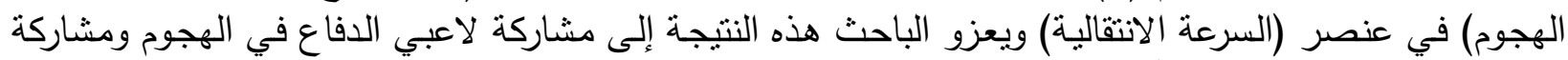

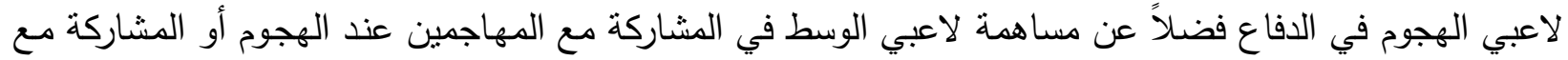

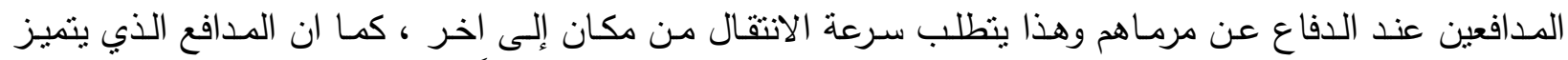

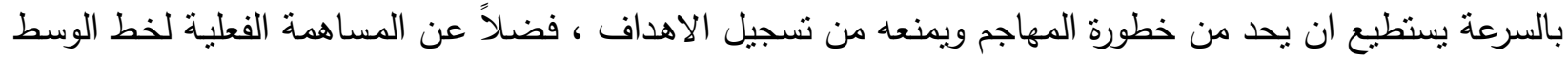

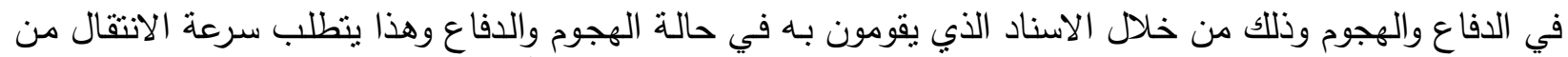

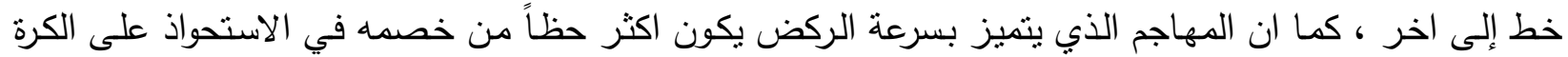

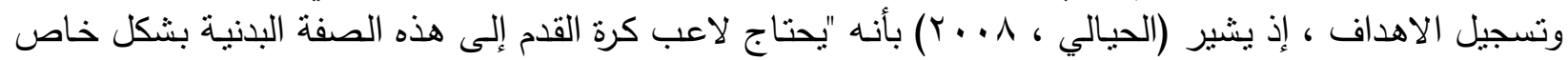

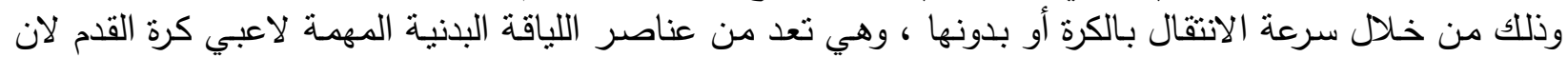

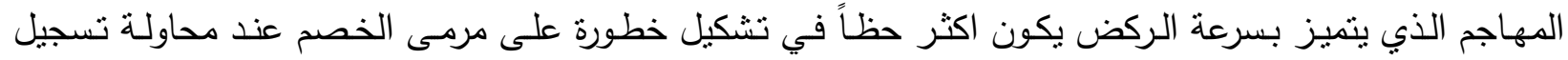

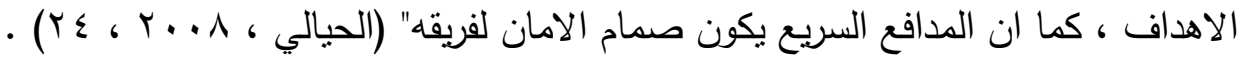

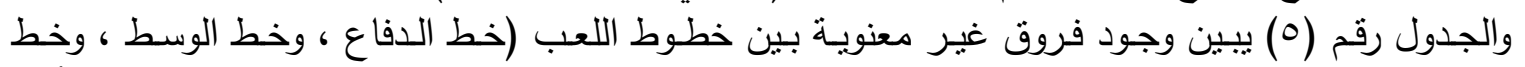

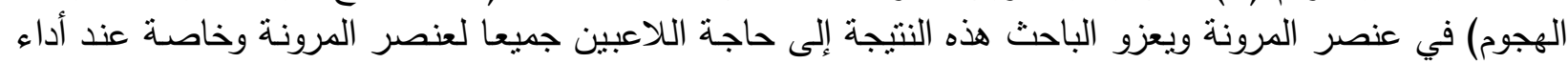

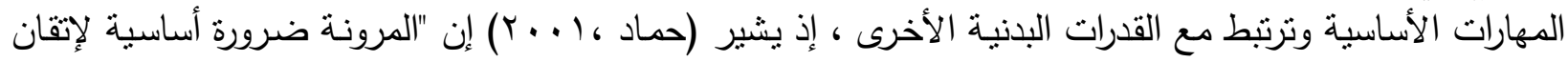

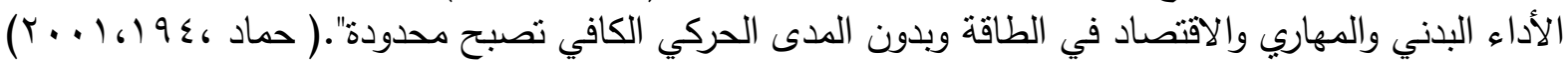




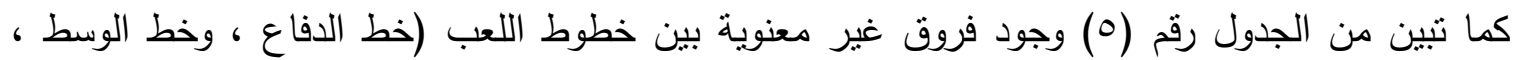

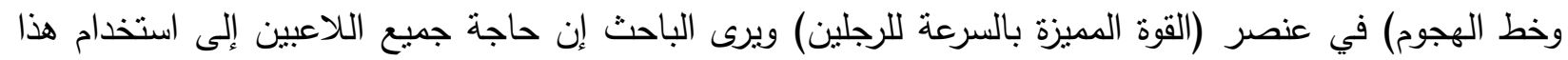

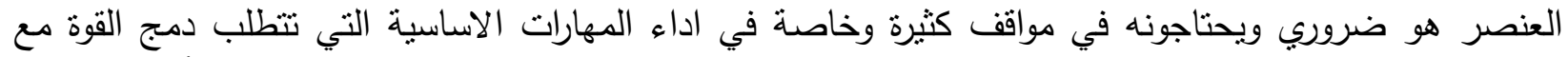

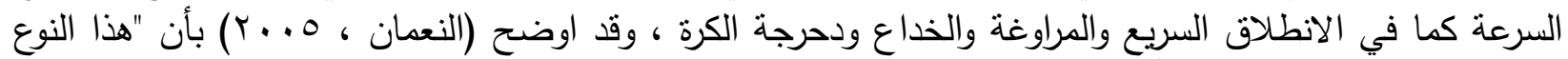

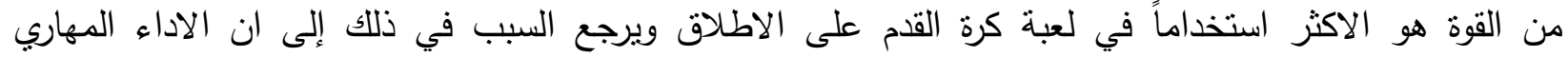

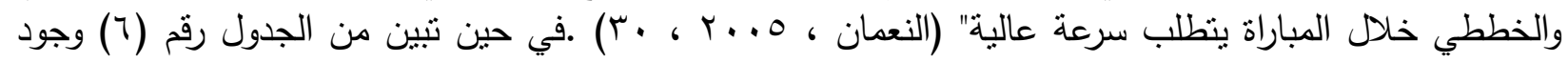

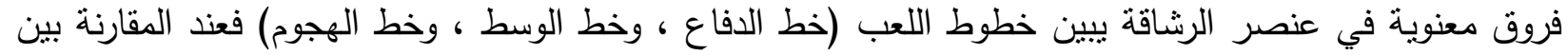

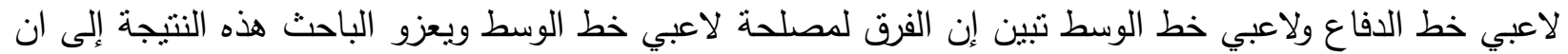

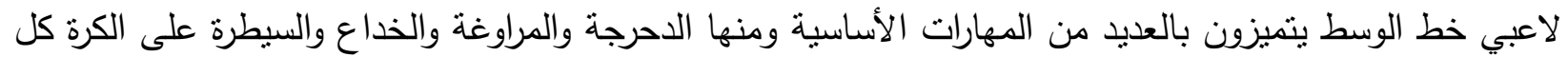

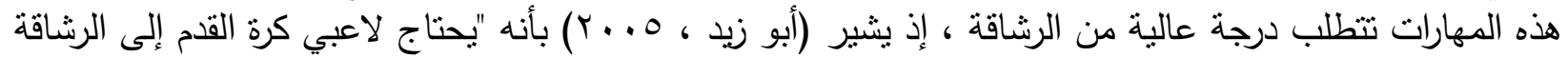

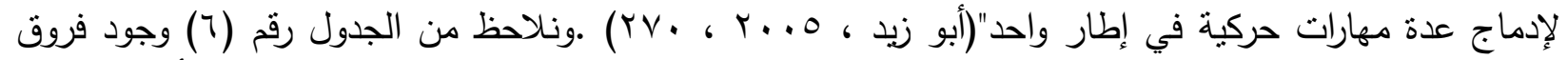

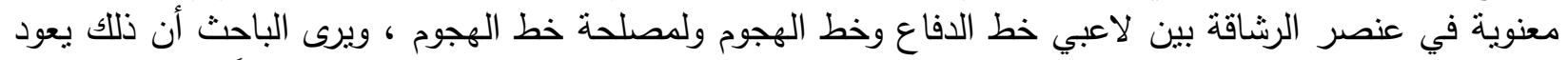

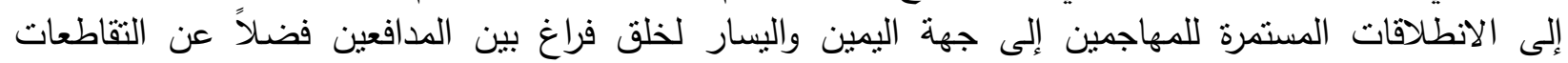

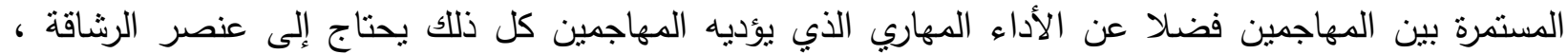

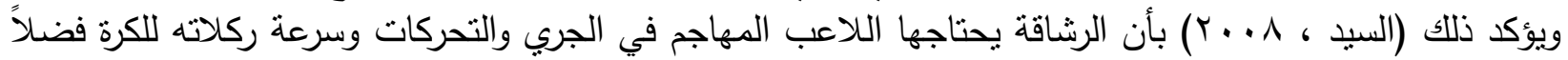

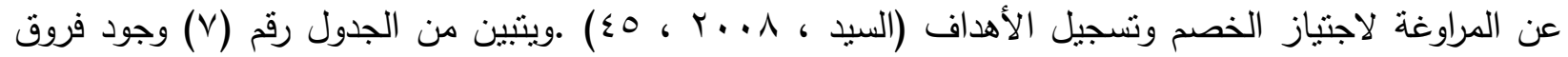

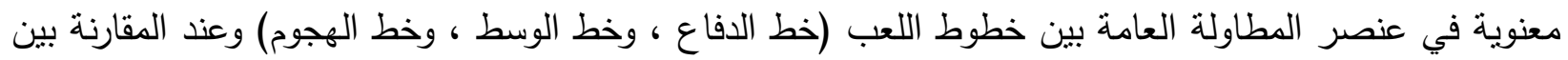

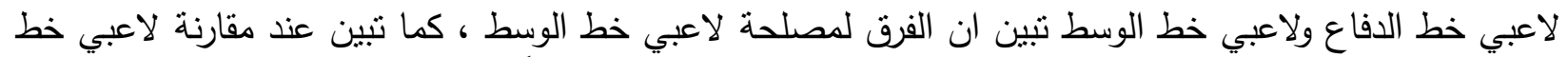

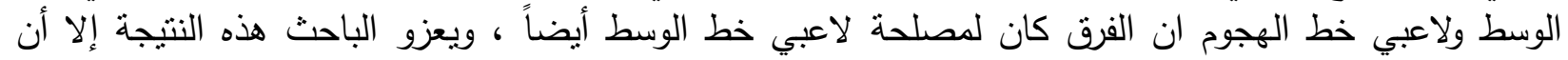

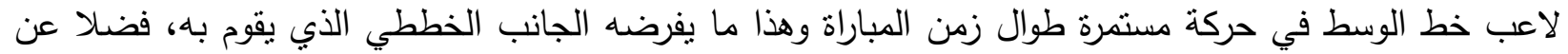

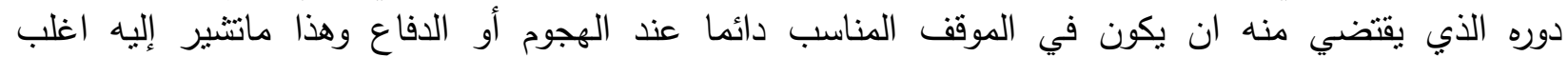

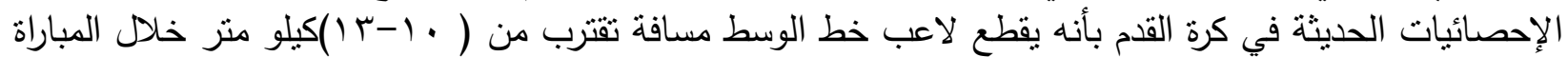

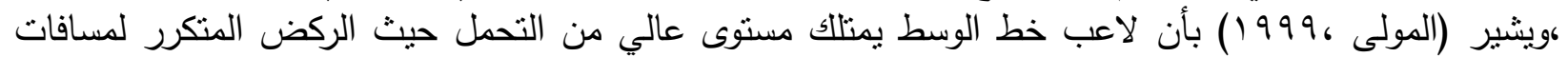

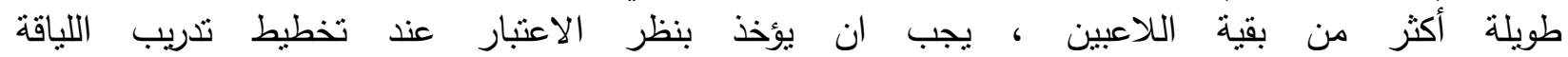

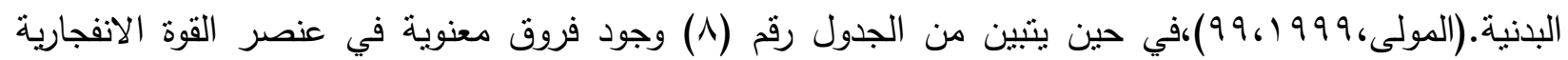

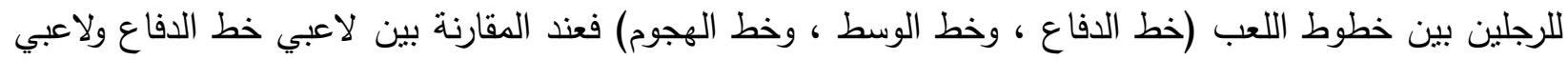

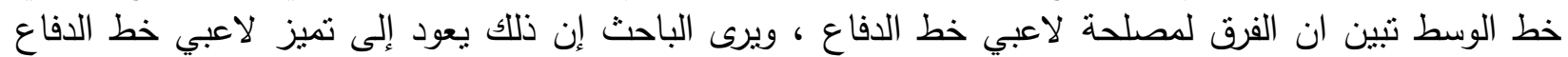

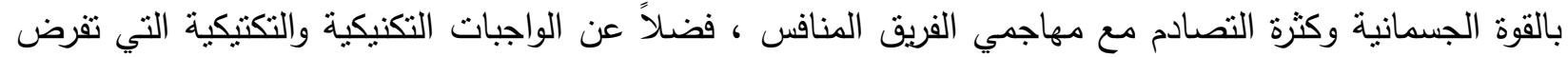

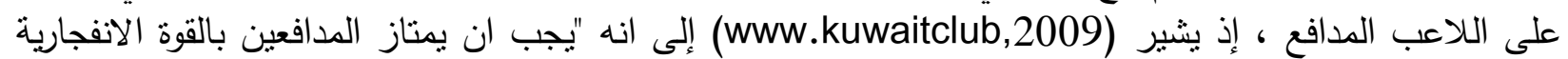

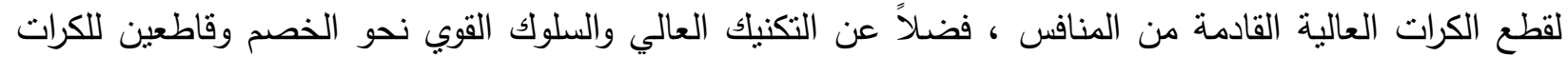

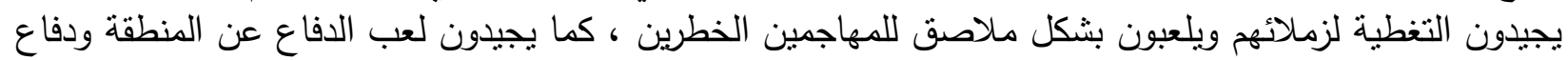

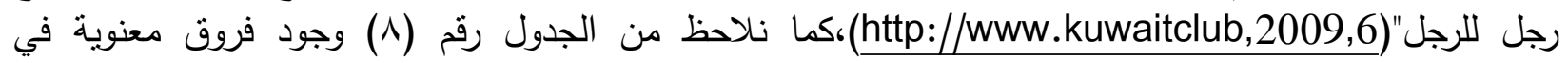

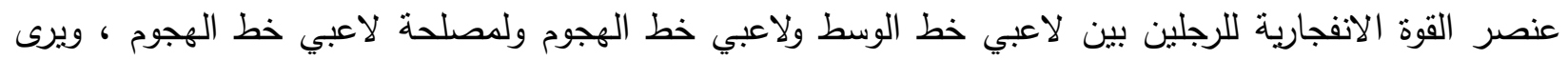

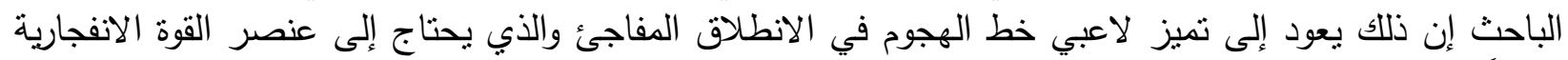

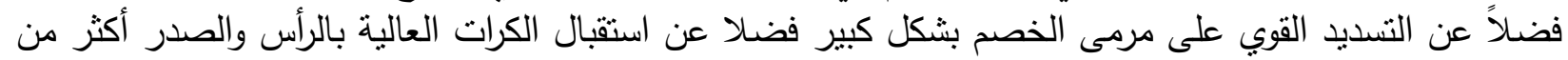

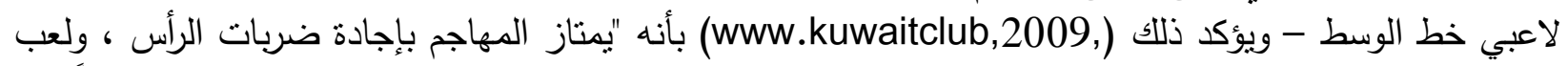

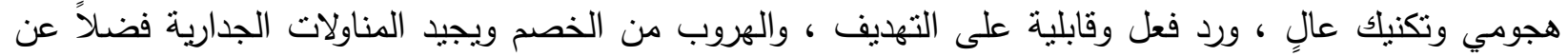

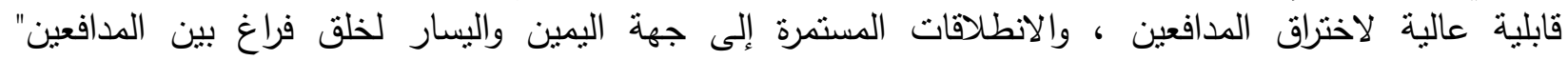
(http://www.kuwaitclub,2009,7)

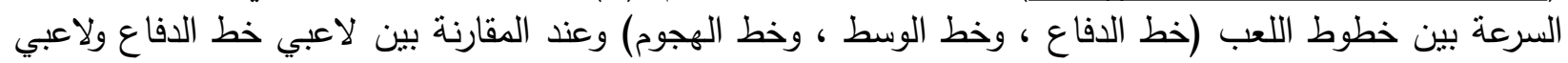

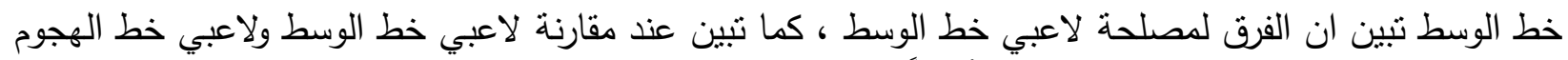

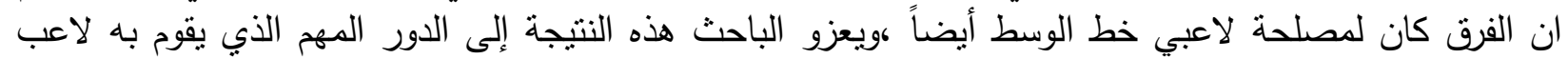

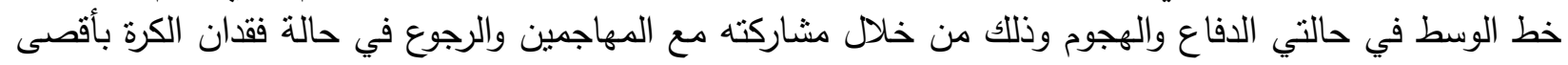




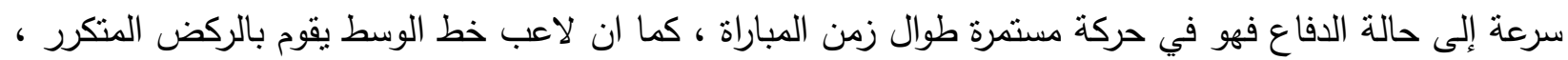

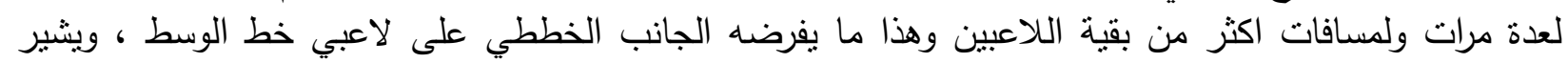

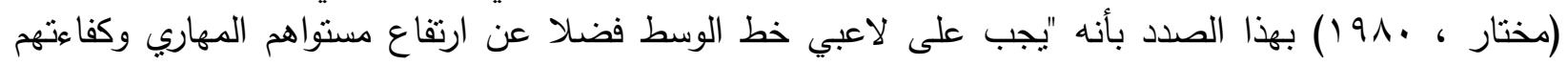

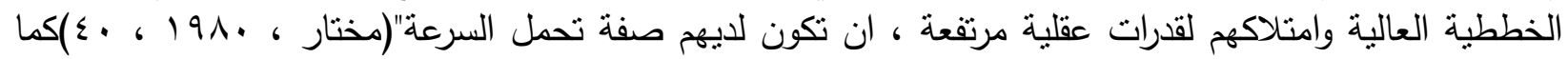

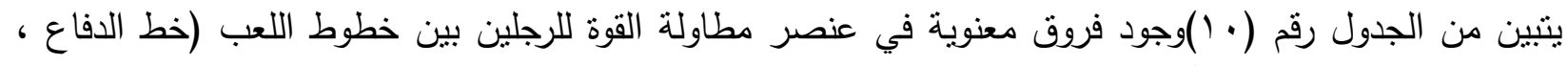

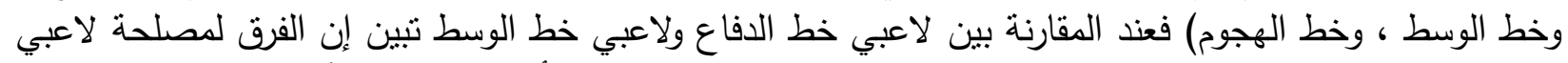

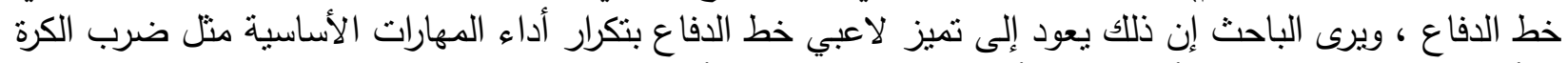

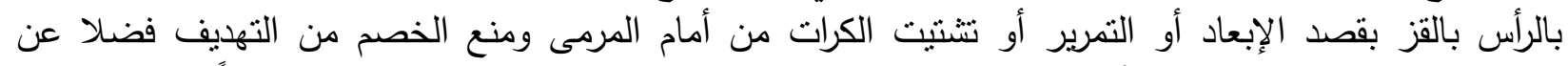

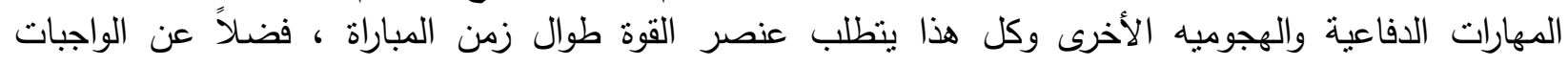

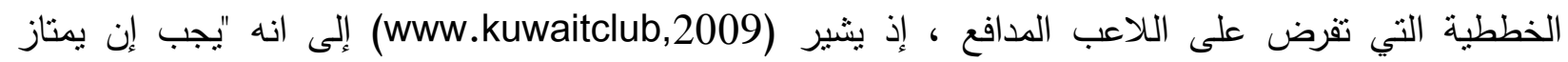

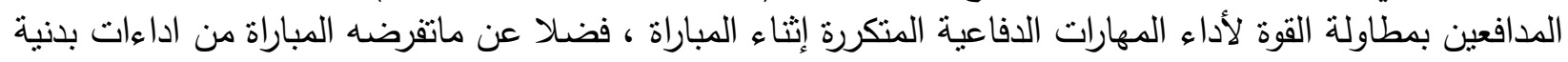

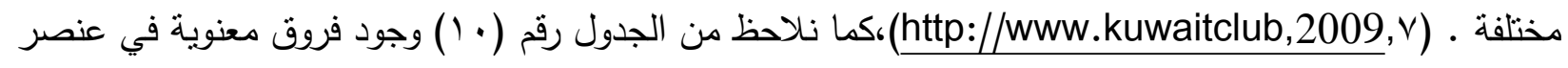

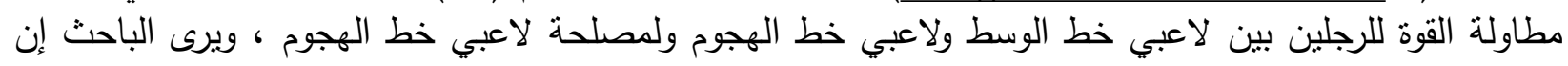

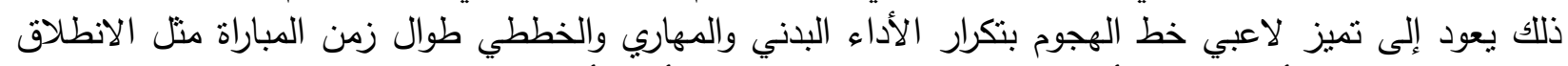

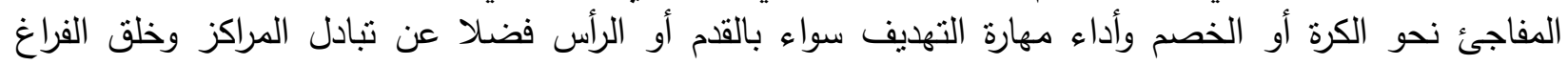

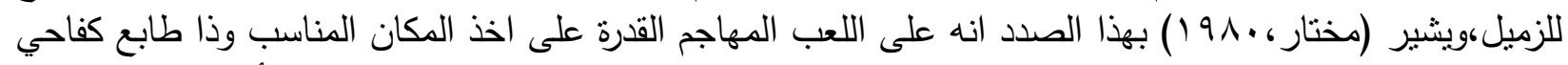

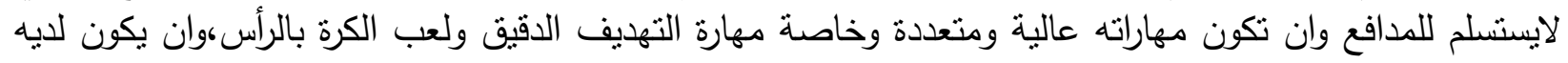

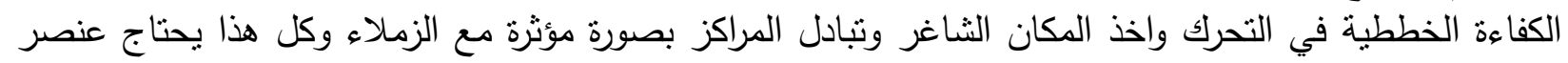

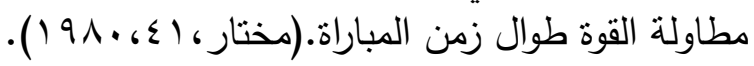

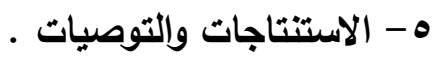
0- 1 - الاستنتاجات .

• هنـاك اختلاف في بعض عناصـر اللياقـة البدنيـة العامـة والخاصـة ( الرشـاقة، والمطاولـة العامـة، والقوة الانفجاريـة

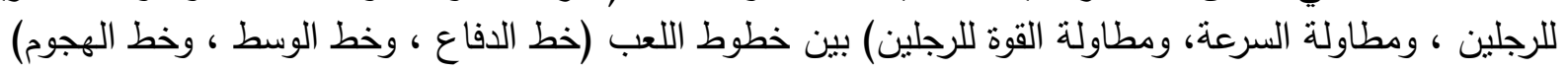

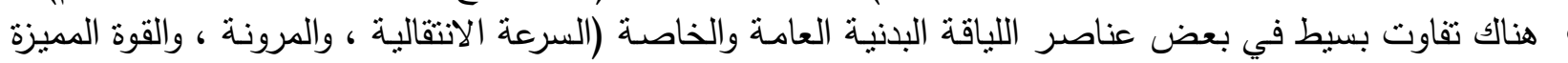

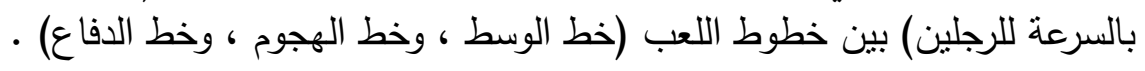

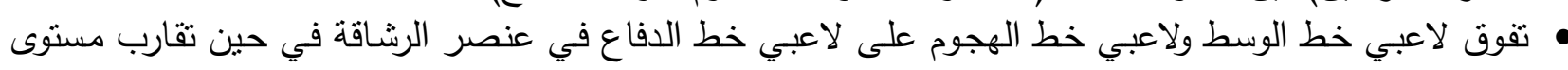

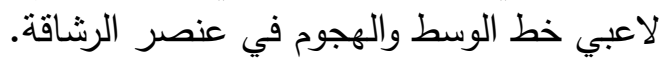

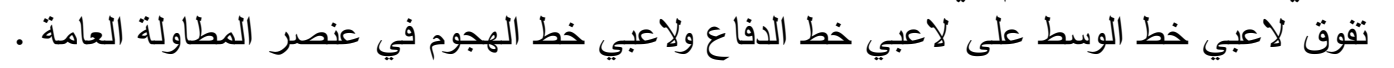

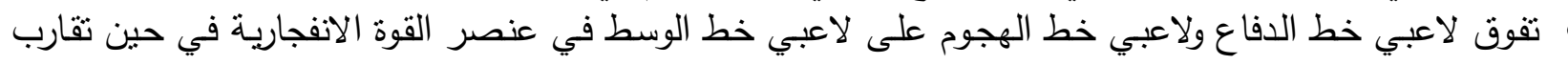

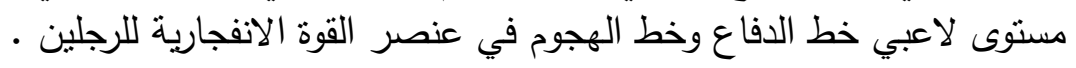

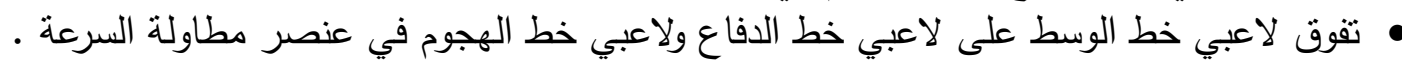

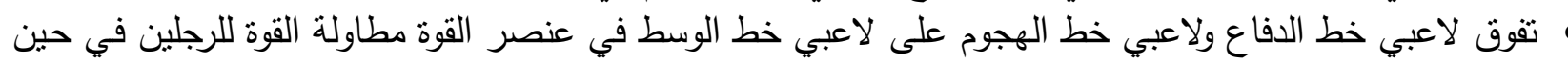

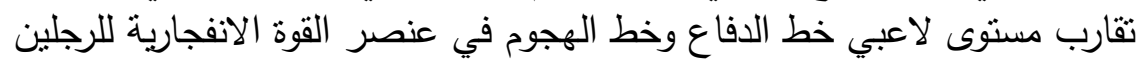

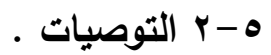
• التأكيد على التدريب الفردي أو التخصصي للاعبين على وفق خطوط لعبهم وبمـا يتلائم مـع الجوانب البدنية

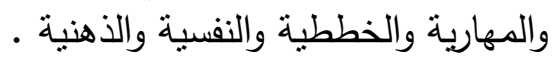
المصادر العربية والاجنبية : المطية

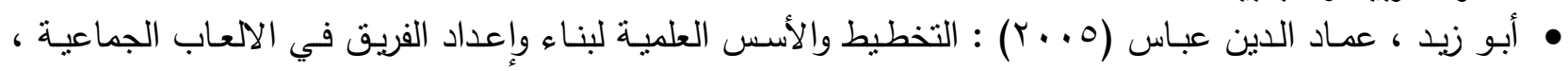

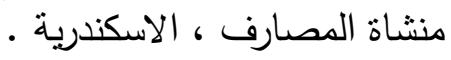
• اسماعيل ، طه وآخرون (919 19) : كرة القدم بين النظرية والنطبيق ، دار الفكر للطباعة والنشر ، عمان ، الاردن

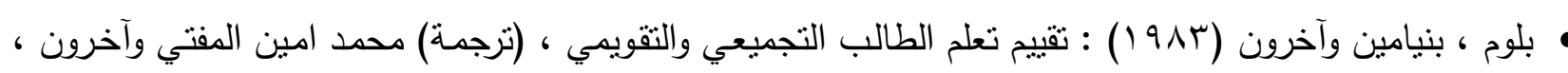

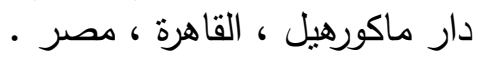




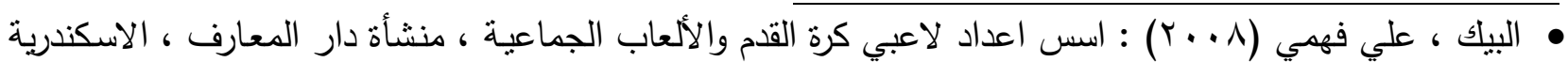

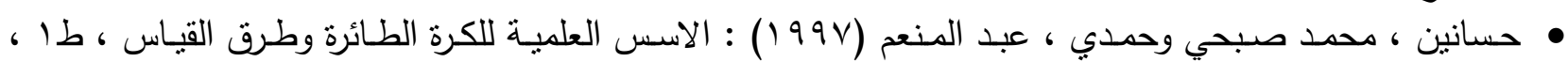

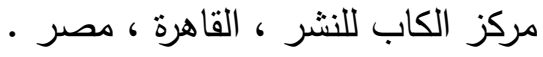

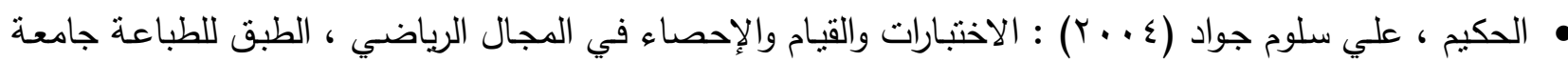
القادسية ، العراق •

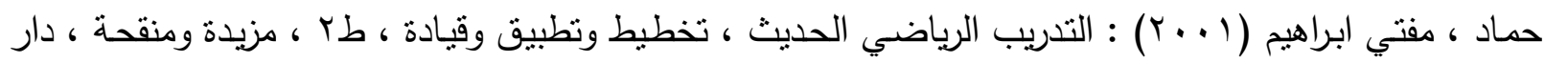

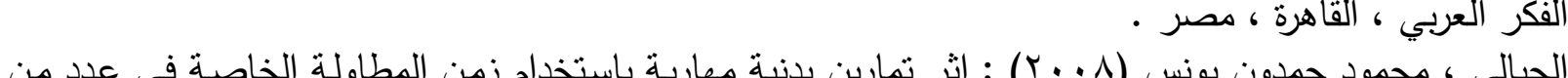

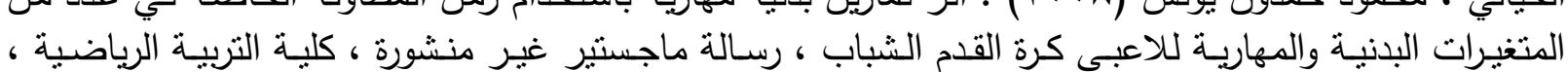
جامعة الموصل .

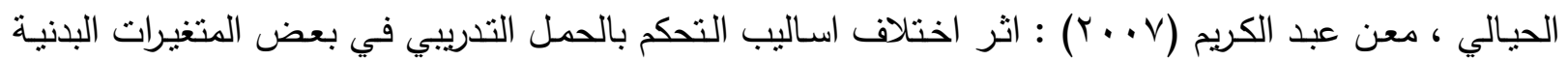

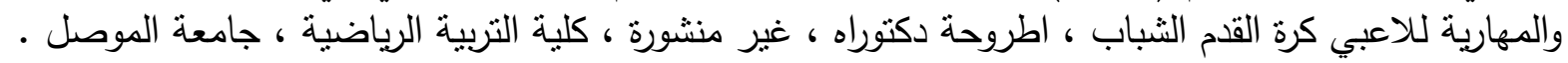

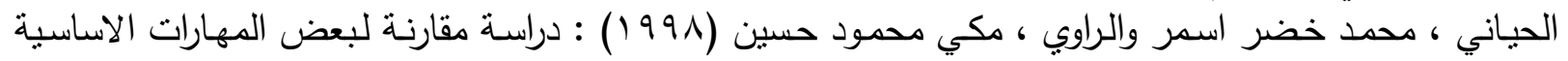

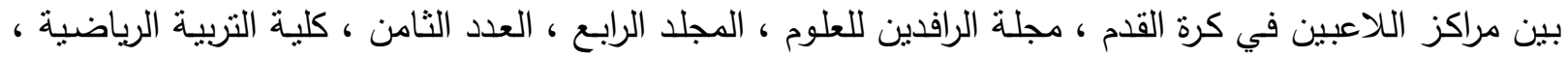
جامعة الموصل . لمراعن

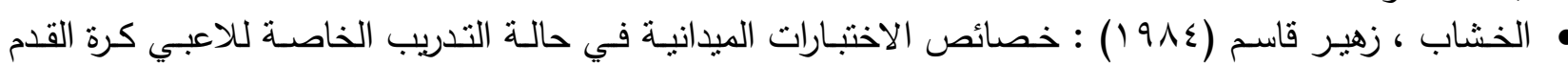

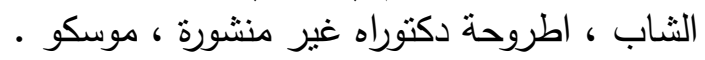

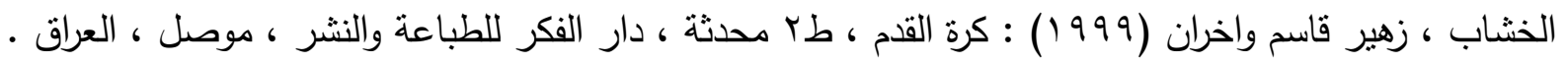

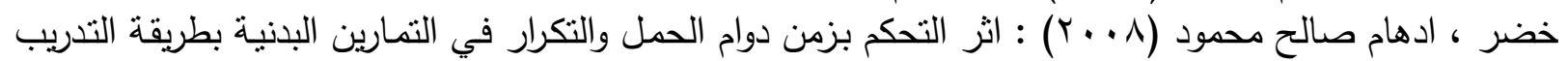

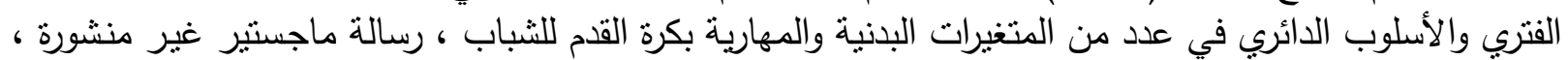

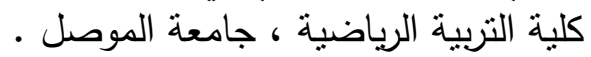

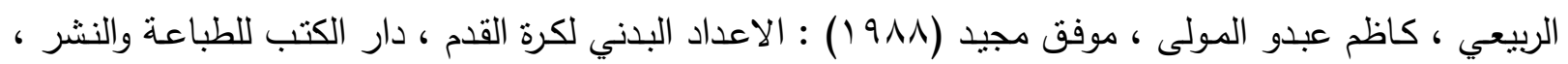

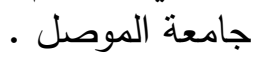

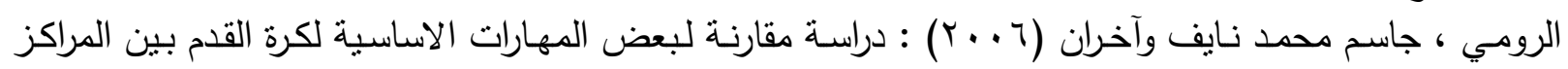

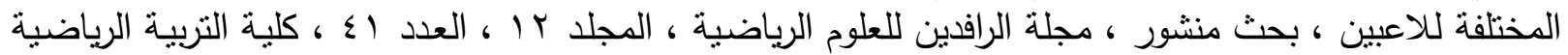

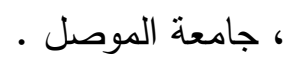

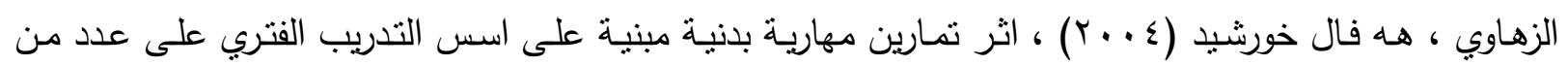

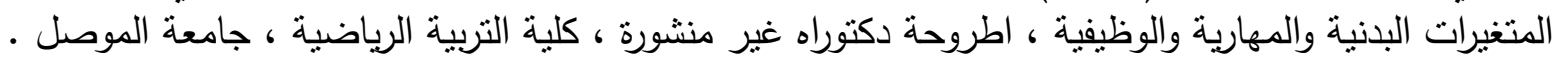

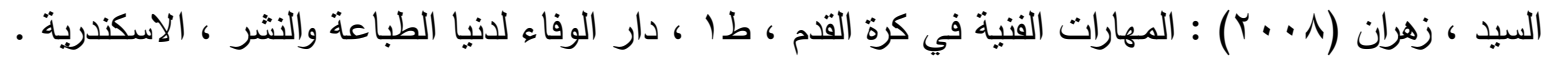

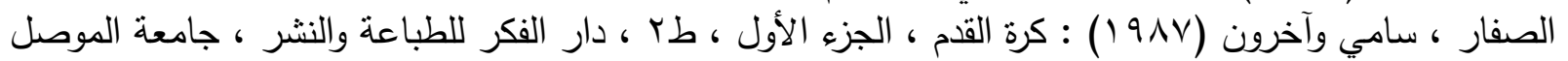

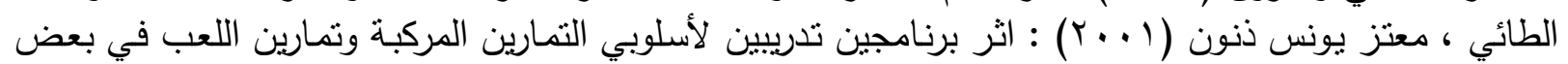

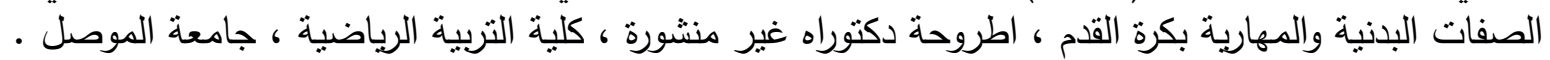

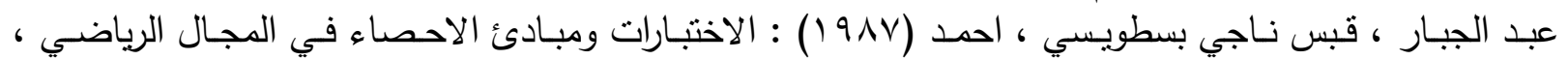

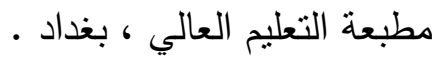

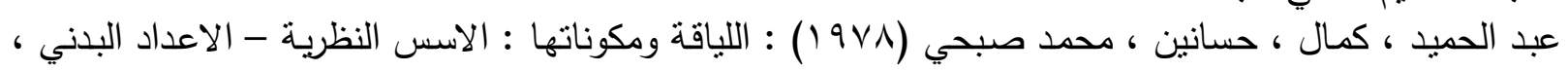

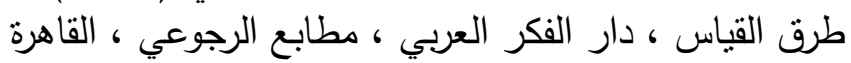

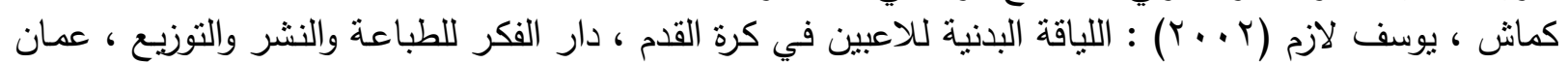

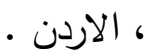

• مختار ، حنفي محمود (·1911) : مدرب كرة القدم ، دار الفكر العربي ، القاهرة .

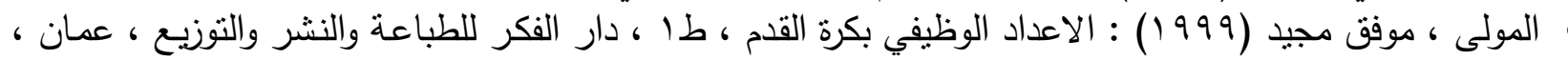

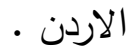

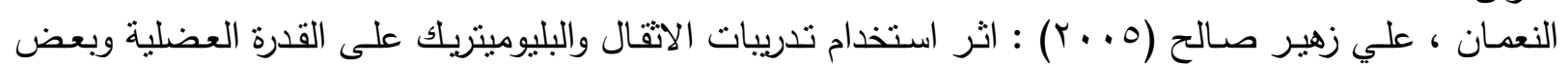

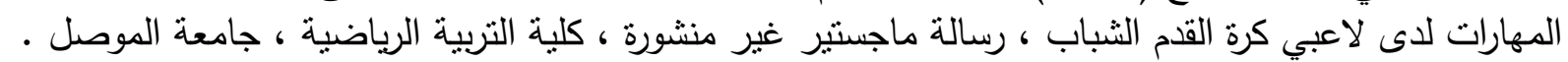


- Bauer, cerhard (1993) : soccer techniques, tactics and teamwork sterling publishing com . Inc, New York .

- Smith, mike (1983) : success in football, success sports Books , 3 addition , Hong Kong .

- http://forum.kooora.com/F.aspx(2009) .

- http://www.kuwaitclub.com.kw/showthread.php(2009) .

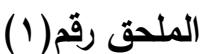

استمارة استبيان لتحديد الهم عناصر اللياقة البذنية

ماستمارة استبيان

جامعة الموصل المحترم كلية التربية الرياضية

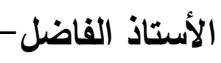

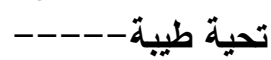

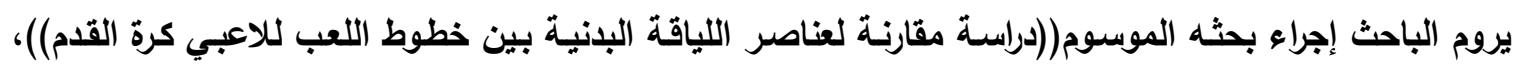

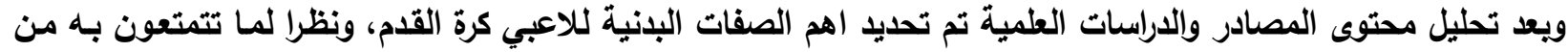
خبرة ودراية علمية وعملية في هذا المجال، يرجى تحديد الهم هذه الصفات والتي تخدم الهداف البحث. ولكم الكم منا فائق الشكر

*ملاحظة/ يرجى وضع علامة ( ـ ) امام الصفة البذنية المناسبة والتي تخدم اهداف البحث، وإضـافة أي صفة بدنية يراها المختص التقدير الاختصاص : (التارخ : الاسم الكامل : المنتصبة ولم تذكر في استمارة الاستبيان.

التاريخ :

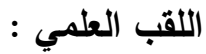

التوقيع :

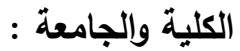

\begin{tabular}{|c|c|c|}
\hline \multicolumn{2}{|c|}{ الإثارة } & عناصر البدنية العامة والخاصة \\
\hline( & ) & إلـالسرعة الانتقالية \\
\hline( & ) & r r الرشاقة \\
\hline( & ) & بـ- المطاولة العامة \\
\hline( & ) & ع المرونة \\
\hline( & ) & 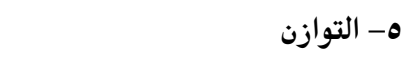 \\
\hline( & ) & ج - -الدقة \\
\hline( & ) & 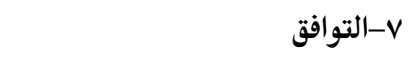 \\
\hline( & ) & ^- القوة الانفجارية للرجلين \\
\hline( & ) & ه- القوة الانفجارية للذراعين \\
\hline( & ) & • ا- القوة المميزة بالسرعة للرجلين \\
\hline( & ) & 11- القوة المميزة بالسرعة للذراعين \\
\hline( & ) & r ا - القوة المميزة بالسرعة للبطن \\
\hline( & ) & سا ب- مطاولة السرعة \\
\hline( & ) & ع ا- مطاولة القوة للرجلين \\
\hline( & ) & 10- مطاولة القوة للذراعين \\
\hline( & ) & 1 1 - مطاولة القوة للبطن \\
\hline
\end{tabular}

الملحق رقم (ץ) أسماء السادة المختصين الأين تم عرض استمارة اختيار عناصر اللياقة البذنية العامة والخاصة عليهر

\begin{tabular}{|c|c|c|c|}
\hline الكلية والجامعة & الاختصاص & اللقب العلمي & الاسم \\
\hline كلية التربية الرياضية / جامعة الموصل & بايوميكانيك / كرة قدم & استاذ & د- لؤي غانم الصميدعي \\
\hline كلية التربية الرياضية / جامعة الموصل & تدريب رياضي / كرة قدم & استاذ & لد - زهير قاسم الخشاب \\
\hline
\end{tabular}


دراسة مقارنة لبعض عناصر الاياقة البدنية...

\begin{tabular}{|c|c|c|c|}
\hline كلية التربية الرياضية / جامعة الموصل & تعلم حركي / كرة قدم & استاذ & لد - محمد خضر اسمر \\
\hline كلية التربية الاساسية / جامعة الموصل & تدريب رياضي / كرة قدم & استاذ & لد - معتز يونس ذنون \\
\hline كلية التربية الرياضية / جامعة الموصل & قياس وتقويم / كرة قدم & استاذ & د- مكي محمود حسين \\
\hline كلية التربية الرياضية / جامعة الموصل & تعلم حركي / كرة قدم & مدرس & دـ - نوفل فاضل رشيد \\
\hline كلية التربية الرياضية / جامعة الموصل & تدريب رياضي / كرة قدم & 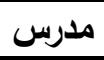 & دـ - معن عبد الكريم جاسم \\
\hline كلية التربية الرياضية / جامعة الموصل & تدريب رياضي/كرة قدم & 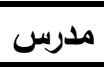 & د - علي زهير صالح \\
\hline عة الموصل & تعلم حركي / كرة قدم & مساعد & 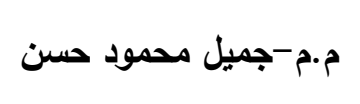 \\
\hline
\end{tabular}

الملحق رقم (ץ)(ستمارة استبيان لتحديد الاختبار الانسب لعناصر اللياقة البذنية المختارة

جامعة الموصل

م / استمارة استبيان كلية التربية الرياضية

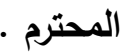
الأستاذ الفاضل التربة الترياض تحية طيبة --- تيناذ الفيل

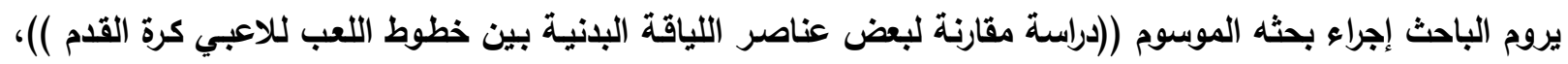

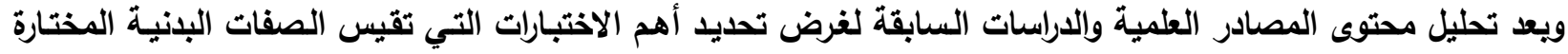

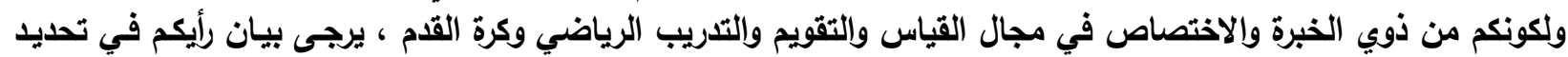

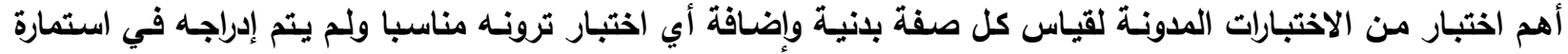

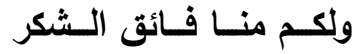

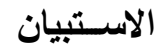

والتقدير ..

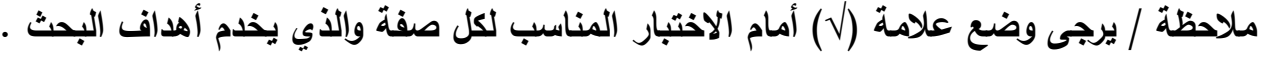
الاختصاص :

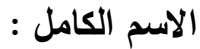

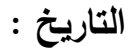

اللقب العلمي :

التوقيع :

الكلية والجامعة : 
دراسة مقارنة لبعض عناصر الاياقة البدنية،....

\begin{tabular}{|c|c|c|c|}
\hline 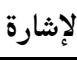 & & الاختبار & عناصر اللياقة البدنية العامة والخاصة \\
\hline( & ) & اختبار ركض (•r )م من بداية متحركة & \multirow{3}{*}{ السرعة الانتقالية } \\
\hline( & ) & اختبار ركض( • • ) م من وضع الوقوف & \\
\hline( & ) & اختبار ركض (•r) م من وضع الوقوف & \\
\hline( & ) & 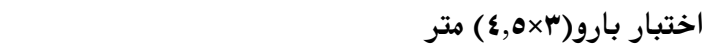 & \multirow{3}{*}{ 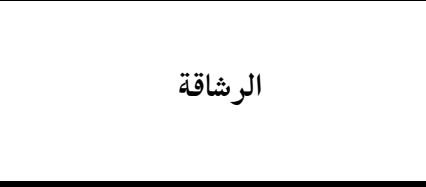 } \\
\hline( & ) & اختبار الركض المتعدد الجهات & \\
\hline( & ) & اختبار الجري المكوكي( \& × · ) م & \\
\hline( & ) & اختبار ركض(· · · (1)م من وضع البدء العالي & \multirow{3}{*}{ 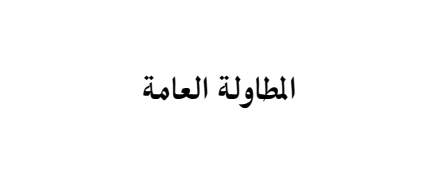 } \\
\hline( & ) & اختبار ركض(· • 10)م من وضع البدء العالي & \\
\hline( & ) & 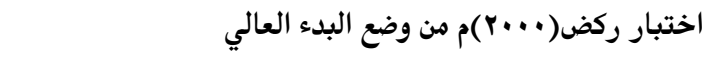 & \\
\hline( & ) & اختبار ثني ومد مفصل الركبة & \multirow{3}{*}{ 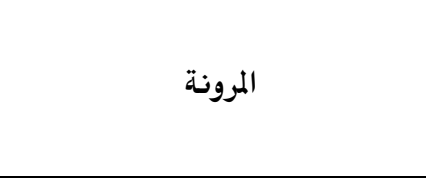 } \\
\hline( & ) & اختبار تبعيد مفصل الفخذ & \\
\hline( & ) & اختبار ثني ومد الجذع إلى الإمام والأسفل & \\
\hline( & ) & اختبار القفز العمودي في الثبات & \multirow{3}{*}{ القوة الانفجارية للرجلين } \\
\hline( & ) & اختبار الوثب الطويل من الثبات & \\
\hline( & ) & اختبار ابالاكوف & \\
\hline( & ) & اختبار الوثب الطويل إلى الأمام( •(1) ثا & \multirow{3}{*}{ القوة المميزة بالسرعة للرجلين } \\
\hline( & ) & اختبار الحجل على رجل واحدة (•r) م & \\
\hline( & ) & اختبار ثلاث حجلات لأكبر مسافة ممكنة ولكل رجل على حدة & \\
\hline( & ) & اختبار ركض( •01 ) م من وضع البدء العالي & \multirow{3}{*}{ 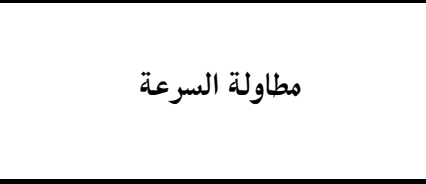 } \\
\hline( & ) & اختبار ركض( •11) م مرتد بأربعة شواخص & \\
\hline( & ) & اختبار ركض (Pr l ) م من وضع البدء العالي & \\
\hline( & ) & اختبار القفز للأعلى من وضع الجلوس لمدة (•ه)ثانية & \multirow{3}{*}{ 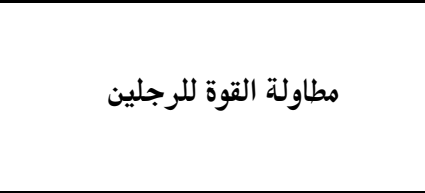 } \\
\hline( & ) & اختبار ثني ومد الرجلين من الركبتين حتى استنفاذ الجهد & \\
\hline( & ) & اختبار الحجل المستمر بالقدمين لقطع اكبر مسافة خلال دقيقة & \\
\hline
\end{tabular}

الملحق رقم(ع)(سماء السادة المختصين الأين تم عرض استمارة اختيار الاختبارات عليهم

\begin{tabular}{|c|c|c|c|}
\hline الكلية والجامعة & 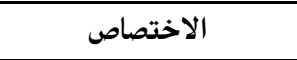 & اللقب العلمي & 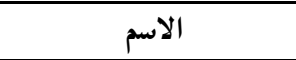 \\
\hline كلية التربية الرياضية / جامعة الموصل & تدريب رياضي / كرة قدم & 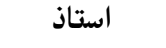 & د- زهير قاسم الخشاب \\
\hline كلية التربية الرياضية / جامعة الموصل & تعلم حركي / كرة قدم & 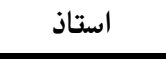 & د- محمد خضر اسمر \\
\hline كلية التربية الرياضية / جامعة الموصل & 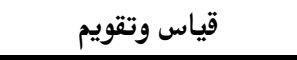 & استاذ & د- هاشم احمد سليمان \\
\hline كلية التربية الرياضية / جامعة الموصل & تدريب رياضي & 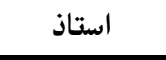 & د- إياد محمد عبد الله \\
\hline كلية التربية الاساسية / جامعة الموصل & تدريب رياضي / كرة قدم & استاذ & د- معتز يونس ذنون \\
\hline كلية التربية الرياضية / جامعة الموصل & قياس وتقويم / كرة قدم & استاذ & د- مكي محمود حسين \\
\hline كلية التربية الرياضية / جامعة الموصل & تدريب رياضي & 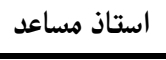 & د- نوفل محمد الحيالي \\
\hline كلية التربية الرياضية / جامعة الموصل & 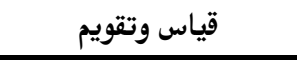 & أستاذ مساعد & د- سبهان محمود \\
\hline كلية التربية الرياضية / جامعة الموصل & قياس وتقويم / كرة قدم & 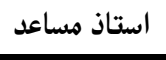 & د- وليد خالد رجب \\
\hline كلية التربية الرياضية / جامعة الموصل & تدريب رياضي & 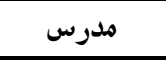 & د- نبيل محمد عبد الله \\
\hline كلية التربية الرياضية / جامعة الموصل & تعلم حركي / كرة قدم & 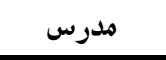 & د- دوفل فاضل رشيد \\
\hline كلية التربية الرياضية / جامعة الموصل & تدريب رياضي / كرة قدم & 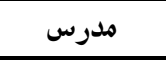 & د- معن عبد الكريم جاسم \\
\hline
\end{tabular}

